\title{
Writing Edwardian Postcards ${ }^{1}$
}

This is the peer reviewed version of the following article: Gillen. J. (2013) Writing

Edwardian Postcards. Journal of Sociolinguistics 17 (4) 488-521, which has been published in final form at http://onlinelibrary.wiley.com/doi/10.1111/josl.12045/abstract. This article may be used for non-commercial purposes in accordance With Wiley Terms and Conditions for selfarchiving.

The Picture Postcard was an extraordinarily popular innovation at the beginning of the twentieth century in Europe, enabling writers to send brief, multimodal messages through a cheap communications channel, in a ‘culture of speed' (Keep 2001). With several deliveries a day, the experience could be closer to the synchronicity of the digital communications than vernacular written communications in the intervening period, enabling a sense of presence (Milne 2010). I examine the writing of ten British Edwardian picture postcards from a collection of three thousand. Analysis of the writing, writtenness and multimodality (Lillis and McKinney this volume) of the postcards is combined with historical investigations of public records in an endeavour to approach an emic understanding of the writers' practices. Through this innovative approach to the construction of text histories, I demonstrate the value of applying the ethnographic sensibility of Literacy Studies to these communications that accomplished diverse and rich purposes.

Å skrive Edvardianske postkort

Bildepostkortet som var en meget populær innovasjon på begynnelsen av det 20nde århundre, gjorde det mulig for skribenter å sende korte multimodale beskjeder ved å ta i bruk en billig 
kommunikasjonskanal, i en “hurtighetskultur” (Keep, 2001). Med flere leveranser per dag kunne kommunikasjonen oppleves som likere synkronisiteten ved digital kommunikasjon enn regulær skriftlig kommunikasjon. Dette muliggjorde en følelse av nærhet (Milne 2010). I denne artikkelen vil jeg studere skrivemåten i ti Edvardianske bildepostkort. Disse ble valgt ut fra en kolleksjon på 3000 postkort. Analyse av skrivemåten, skriftligheten og multimodaliteten (Lillis and McKinney this volume) i postkortene kombineres med historiske undersøkelser av offentlige arkiver for å etablere en emisk forståelse av postkortforfatternes praksiser. Gjennom en slik innovativ tilnærmingsmåte til konstruksjonen av teksthistorier, vil jeg vise verdien av å utvise en etnografisk følsomhet overfor disse kommunikasjonsformene som oppfylte mangefasetterte og rike formål.

keywords: digital communications; history; literacy studies; multimodality; postcards; presence; writing 


\section{INTRODUCTION -WRITING POSTCARDS IN AN ERA OF CHANGE}

Edwardian postcards have been largely overlooked as a rapid written communications technology, epitomising the sense of a society as living in a 'culture of speed' (Keep 2001: 151). Blom (2008: 2) wrote of the Edwardian period²:

Then as now, rapid changes in technology, globalization, communication technologies and changes in the social fabric dominated conversations and newspapers articles; then as now, cultures of mass consumption stamped their mark on the time; then as now, the feeling of living in an accelerating world.... was overwhelming.

In its own time, at the beginning of the twentieth century the picture postcard was considered to epitomise the spirit of the times, 'a candid revelation of our pursuits and pastimes, our customs and costumes, our morals and manners.' (Douglas 1909: 377). Indeed, some of these pictures have survived as collectibles from a period when photography became accessible to the masses in this form, perhaps the most popular category of ephemera amassed by those unsurpassed generations of collectors, the late Victorians and Edwardians (Donnachie and Macleod 1979; Rogan 2005; Malcolm and Becker 2008).

Communicative practices are historical and experiential emergents, (Bauman 2010). The early postcard represented a new epistolary space, one which suited the turn of the nineteenth century into the twentieth with its greater than ever social and physical mobility (Siegert 1999; Milne 2010). Vincent (2000) locates the rise of mass literacy as coterminous with the Post Office, which carried vast quantities of written communications among people of virtually all social sectors. After more than 30 years of universal education, the population 
had attained its final modern plateau of literacy (Altick 1957). The rapid speed of deliveries in the late Victorian and Edwardian period led to a sense of something like sychronicity, since letters and cards could arrive from early in the morning till late at night (Carline 1971; Staff 1979; Daunton 1985). The Manchester Weekly Times predicted in 1890 (June $4^{\text {th }}$ ), 'The work of correspondence will be reduced to a minimum when one has only to carry a pack of postcards in one’s pocket, write one's thought in pencil as soon as it occurs, and despatch it through the first messenger or the first receiving box one comes across.' It is not difficult to relate this to the appeal of the seemingly ephemeral digital communications of the current era, such as Twitter, SMS text messaging or email, so easily accessible from a variety of digital devices, many of them portable (Malcolm and Becker 2008; Milne 2010).

Historical attention to vernacular epistolary texts has been rare (How 2003), albeit with a few notable exceptions, such as the creativity revealed in seventeenth and eighteenth century pauper letters by Sokoll (2001) and in an Edwardian courtship correspondence studied by Phillips (1999). Ordinary writing (Sinor 2002; Lyons 2007; Gillen and Hall 2010b) is generally occluded while surviving historical writing is that of elite writers, their clerks and scribes, or belongs to distinctive educated individuals, often diarists. In contrast, today's interest in digital or computer-mediated communications has engendered a considerable and growing amount of scholarly investigation into everyday writing and reading practices (Herring 2004; Thurlow and Mroczek 2011).

Written digital communications have a potential, often realised in practice, to transcend time and space more rapidly than was previously possible. Nevertheless study of epistolary practices at the turn of the twentieth century reveals remarkable symmetries in a cultural perception of presence. The wealthy and educated urban Victorian population in London 
perceived their rapid letter-writing exchanges as virtually synchronous, creating an atmosphere of considerable intimacy or presence (Danet 1997; Milne 2000). The Edwardian picture postcard extended these possibilities to the mass of the population.

It was the image of the picture postcard that was overwhelmingly likely to be the reason for any preservation of these potentially ephemeral communications. Usually initially preserved in albums, some collections have been preserved for historical reasons (Prochaska and Mendelson 2010; Lauder 2012) or in the course of the hobby of deltiology (Siegert 1999 and see Gillen and Hall 2010a for discussion). Academic attention has been leveraged to the possibilities of using them as visual resources to assist cultural studies in specific topics such as tourism ((Thurlow, Jaworski and Ylänne-McEwen 2010), the history of gender politics (Wollaeger 2001; Palczewski 2005) or indeed stressed the diversity of such applications (Stevens 1995).

Some studies have focussed on the interplay between postcard image and message, in specific contexts of use (Laurier and Whyte 2001; Laakso and Östman 2002; Hook 2005; Hall and Gillen 2007; Becker and Malcolm, 2008). Jaworski (2010) examined linguistic landscapes as mediated for tourism and so is particularly interested in writing on cards, but as they were produced for sale rather than added by a sender. Philips (2000) observed that the popularity of the medium could be accounted for by its relatively light demands on formal, educated literacy skills in comparison to the letter.

Rogan (2005) explored how in its Golden Age (approximately 1895-1920) the postcard was a cultural phenomenon across Europe, a craze of modernity. His analysis, based on study of his own collection and secondary sources, defined four main factors to account for their 
popularity: aesthetics of the picture, function as souvenir, collectible object and means of communication. Östman (2004) discussed the postcard as semiotic space and focussed on the semi-public characteristic of postcards, and, drawing on empirical analyses collected by Laakso and Östman (1999), suggests that this causes some indirectness in linguistic strategies.

In Britain, the picture postcard was at the centre of the Edwardians' new communications landscape, to borrow a term from the contemporary digital revolution (Kress 1998). First developed in Austria in 1869, the postcard was very quickly adopted across Europe (Vincent 2000). In Britain the postcard's use was carefully circumscribed by the Post Office. The early postcards were pre-printed, rigidly sized, and pre-stamped; the whole of one side had to be taken up by the address and the other side could only contain the message. People began using postcards in part owing to the degree of brevity needed which had the potential to mitigate against at least some of the formalities of letter writing, taught in schools and through etiquette manuals (Hall and Gillen 2007). In 1899 The Times suggested, 'The postcard with its entire freedom from ceremony of formality, is such an obvious boon to thousands, if not millions, of correspondents in these days.'

In 1894 the Post Office allowed images to appear on postcards, allowing a short message to be written in the margin; this will henceforth be referred to as the turn-of-the-century format. In 1902 there was a further innovation that dramatically increased the attractiveness and popularity of the postcard. New Post Office regulations permitted one whole side to be taken up by an illustration; the other side was divided between half for the stamp, postmark and address and half for the written message. Although still a small space for writing, the possibility for combining a short but meaningful message with a picture was tremendously 
appealing. Photographers and printers spotted the opportunities, helped by cheap paper and advances in accessible printing techniques (Carline 1971; Staff, 1979). Within two years postcard sending rose dramatically, reaching almost a billion cards a year at the end of the Edwardian period. Evidence from the Postmaster General's annual reports reveals that during the reign of Edward VII (1901-1910) the total number of postcards posted in Britain was 5,920,933,334, almost six billion, getting on for 200 cards per person. If it is remembered that many people could not write, being too old or too young, perhaps disabled or illiterate, it is clear that an enormously popular communications revolution was going on. 'In ten years Europe will be buried beneath picture postcards, ' worried the Glasgow Evening News, October 1903 (cited by Carline 1971: 9).

With six or even more deliveries a day in towns and cities, and with a halfpenny stamp, rapid responsivity was enabled in a simple, cheap way (Staff 1979). For the first time in British history there was a means of communication that could be perceived as nearsynchronous, in which a significant part of the overall message could be conveyed by a picture, which gave the potential to avoid lengthy letter writing and for some permitted an informal spontaneity. The relatively formal tenets of letter writing etiquette were underpinned in formal education and prescriptive manuals (e.g. Hunter 1872; A member of the aristocracy 1892; Brooksbank 1908). Britain had experienced almost thirty years of compulsory education, and while literacy levels may not have necessarily been universally high, the postcard did not make huge demands on writers. These potentially gave way in postcard writing to a more vernacular literacy: 'essentially.... not regulated by the formal rules and procedures of dominant social institutions and which [has] origins in everyday life' (Barton \& Hamilton 1998: 247) In their highly accessible multimodality, Edwardian postcards offered 
an opportunity not equalled for a century until multimodal emails and text messages became commonplace.

To a large extent then 1902 was the year that writing postcards became a breakthrough communications technology, a popular phenomenon in Britain, at approximately the same date the craze was discerned across many European countries (Rogan 2005). These cheap and attractive objects seemed appropriate to a newly mobile age, in which people were moving about far more quickly, easily and frequently than before: for example the railways system in Britain was at its zenith, far more extensive than today's network (Thompson 1992).

Social reactions to the postcard can be thought of as prefiguring two of the concerns of a later, newly digital era. For some the postcard was seen to transgress social standards and even lead to a decline in the standard of English language (cf. Tagliamonte and Dennis, 2008). Sims (1900: 22) deplored, 'The postcard is utterly destructive of style, and give absolutely no play to the emotions.' The journalist Douglas (1909: 379) reflected, 'There are still some ancient purists who regard postcards as vulgar, fit only for tradesmen.' A further concern was that the postcard dangerously violated the private/public divide, invading privacy and making visible communications that should be kept hidden. The idea that a postcard was public went beyond the notion that being without an envelope it could potentially be read by for example other members of the household and the local postman. Legally, the postcard was held to be a public communication.

\section{METHODOLOGY}

The route to my historical methodology is founded upon ethnographic approaches to Literacy Studies. The key to this approach is the understanding that texts are produced and read in 
specific situations by people in complex meaning-making practices (Barton 2007; Heath 1983; Street 1984). A text is not independent of any situation in which it is written and/or read; on the contrary meanings are negotiated by people living in societies. People have culturally influenced understandings, purposes and values. Following Bazerman and Prior, my research is designed to approach: 'a means of examining communicative practice so as to uncover signs of social identities, institutions and norms as well as the means by which these social formations are established, negotiated, enacted, and changed through communicative practice.' (Bazerman and Prior 2004: 3).

Thus I work to investigate practices around the writing of Edwardian postcards so that such understandings can enrich analysis of cards as multimodal texts. My questions are: 1. What writing practices were involved in communicating with Edwardian postcards, as revealed through historical investigations?

2. What meaning-making practices can be revealed through examination of the cards as written, multimodal texts?

I see my questions here and methodology as clearly aligned to ethnographic approaches to the study of written communication (Barton and Papen 2010). I am seeking out whatever possibilities there may be for investigating dimensions of the meaning-making practices involved.Taking an ethnographic approach to literacy studies means deploying other, complementary, ways of investigating these 'social identities, institutions and norms' and their sociohistorical backgrounds (Scribner and Cole 1981; Heath 1983; Street 1984, Barton and Hamilton 1998; Johnson and Cowles 2009) This is facilitative of enriching understandings beyond that which may be arrived at through discourse analysis alone. In such literacy studies combining biographic work with sociocultural approaches to the study 
of individuals and their communities has often stemmed from an anthropological orientation; most for ethical reasons dealing with contemporary participants anonymise their informants. Yet Hymes (1982:21) credited history as a discipline as a vital antecedent and source of inspiration for literacy studies and some such research contributing to a historical disciplinary framework does not adopt anonymisation, (e.g. Durston 2008; Cabrita 2010). Nevertheless, apart from the collection of works edited by Barton and Hall (1999) relatively few works that locate themselves centrally in Literacy Studies overtly bridge a historical and contemporary approach to literacy. That collection is also a significant predecessor to this in being concerned with epistolary literacies. I aim to show how constructing text histories, taking a historical approach to the authentic identities of people communicating through the writing and reading of postcards, enables rich readings.

Working with Nigel Hall, I have collected, transcribed and conducted some initial analyses with 3,000 cards that were sent through the post within Great Britain and Ireland between 1901 and 1910. This collection, as any, cannot be proposed to be representative of Edwardian postcards as printed objects, made for sale, in respect of the picture side, owing to biases in issues of preservation and collection (Wall 2007). First, it is likely that often more attractive cards were likely to survive, as preserved in albums. However, our collection process, unlike that of virtually every other collector, has been oriented to the presence of written messages, sent through the post and governed by cost. Postcard collectors almost always focus on image, usually disregarding the presence of writing; we have bought cheap cards of little appeal to typical collectors and indeed purchased them without looking at the picture side. Our collection does not include cards with high production values or greatly prized images, although indeed such may have been more expensive at point of original sale and so potentially less common in the Edwardian era. So it might just be possible that these 
biases to some extent work against one another. There is certainly no way of knowing if our images are in any sense representative of what was available at the time. The focus of this project is on the writing that people did on cards having bought (or occasionally made) them, and then sent them through the post. Visual analysis of the picture is limited to the approach taken by Becker and Malcolm (2008b np.) in their study of a corpus of 350 Edwardian postcards, considering 'how the message of the visual text reinforces, extends and/or challenges the message of the verbal text.'

For this paper I draw on ten cards selected at random, that I then investigate with the aid of historical sources. The issue of random selection is always problematic, but after the initial analysis of 3,000 cards any principled selection for a criterion of representativeness would have privileged one or more specific categorisation employed such as date; gender of writer and/or sender; length of message; distance sent; layout; writing technology; orthography; reference to other messages including letters; presence of other cards in our collection to the same sender, etc. Even without considering a priori the apparent function of the communication, or topics written about, no single strategic basis for selection of a sample appeared justifiable, given the relative openness of the research questions and overall ethnographic sensibility. So a random selection of ten cards is presented, although in interpretation some knowledge of the wider collection is drawn upon where relevant. Furthermore, the challenge of constructing text histories of ten cards, without pre-selecting them for the availability of historical records, can lead to some tentative conclusion about the overall viability of such a method. In addition, I draw on other contemporary discussion of postcards, especially in newspapers as well as histories of the period and its communications in particular. 
My aim is to explore the writing of cards as a practice, drawing on the framework of understanding writing set out by Lillis and McKinney (this volume), slightly adapted as follows.

Writing involves:

1. inscription, acts of mark-making;

2. semiotic practice, the use of symbols appropriated through cultural-historical understandings;

3. materiality, according to technological resources available;

4. multimodality, both in the graphic design of the message and relation to the picture;

5. mobility across time and space;

6. a range of social and communicative functions;

7. instantiations of social practice.

My historical method was to investigate the addressees through available census records, especially those of 1901 and 1911, supplemented by engagement with other public records such as commercial directories and maps. In the UK a national census has been taken every ten years; detailed records are released once they are a hundred years' old. An inherent limitation is that it is usually only possible to find information about the addressee rather than the sender who is rarely identifiable.

Reproductions of both sides of each card appear on the journal's website in colour. For reasons of space it is impossible to present all these here, although a few key reproductions 
are included, albeit monochrome. Therefore a preliminary description of each card and transcription of the written message appears in an initial table.

TEN EDWARDIAN POSTCARDS

Card 1 

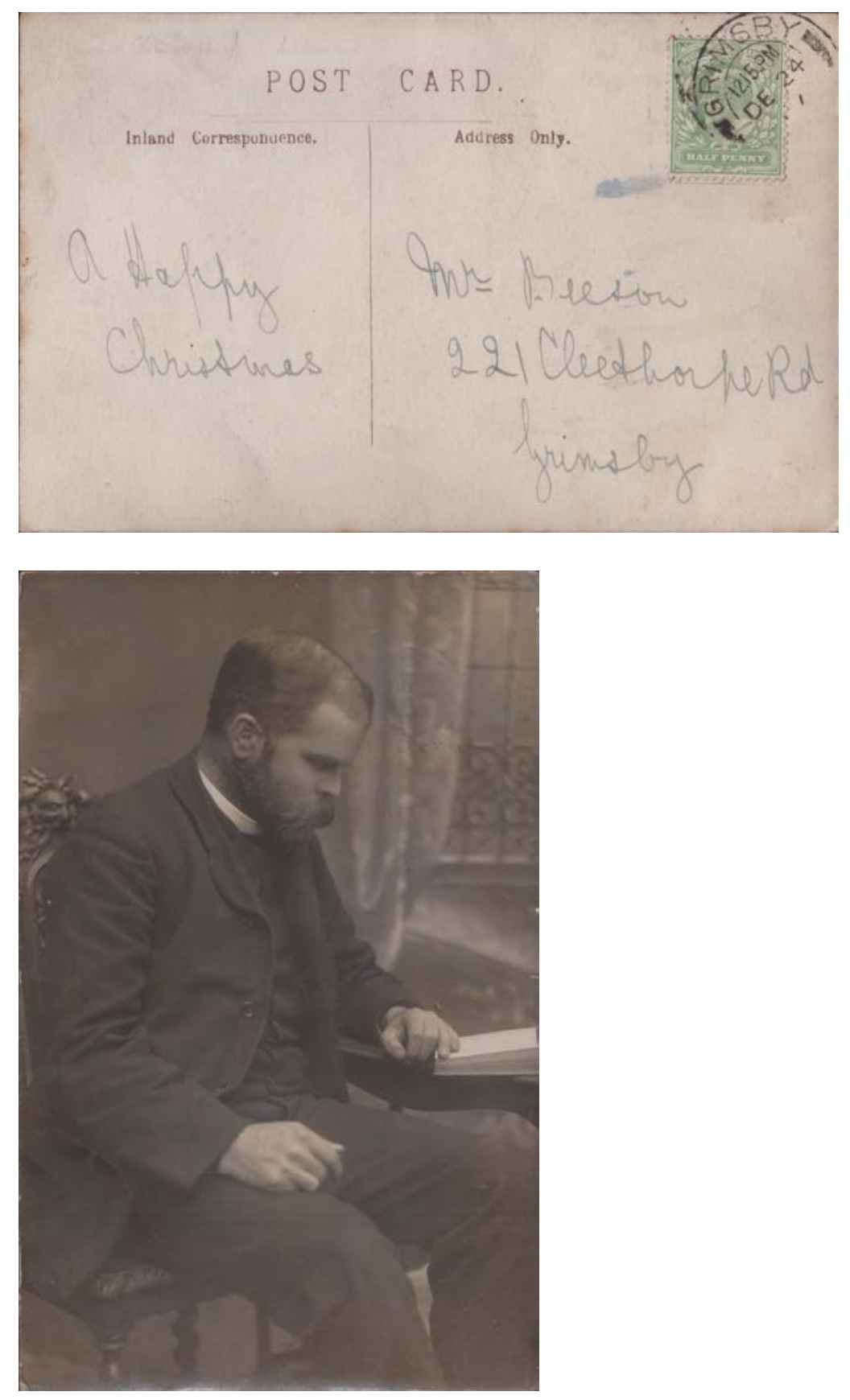

Table 1 Card 2601

\begin{tabular}{|l|l|l|l|}
\hline Postmark & Addressee & Transcript of & Description of \\
& & message side & picture side \\
\hline
\end{tabular}




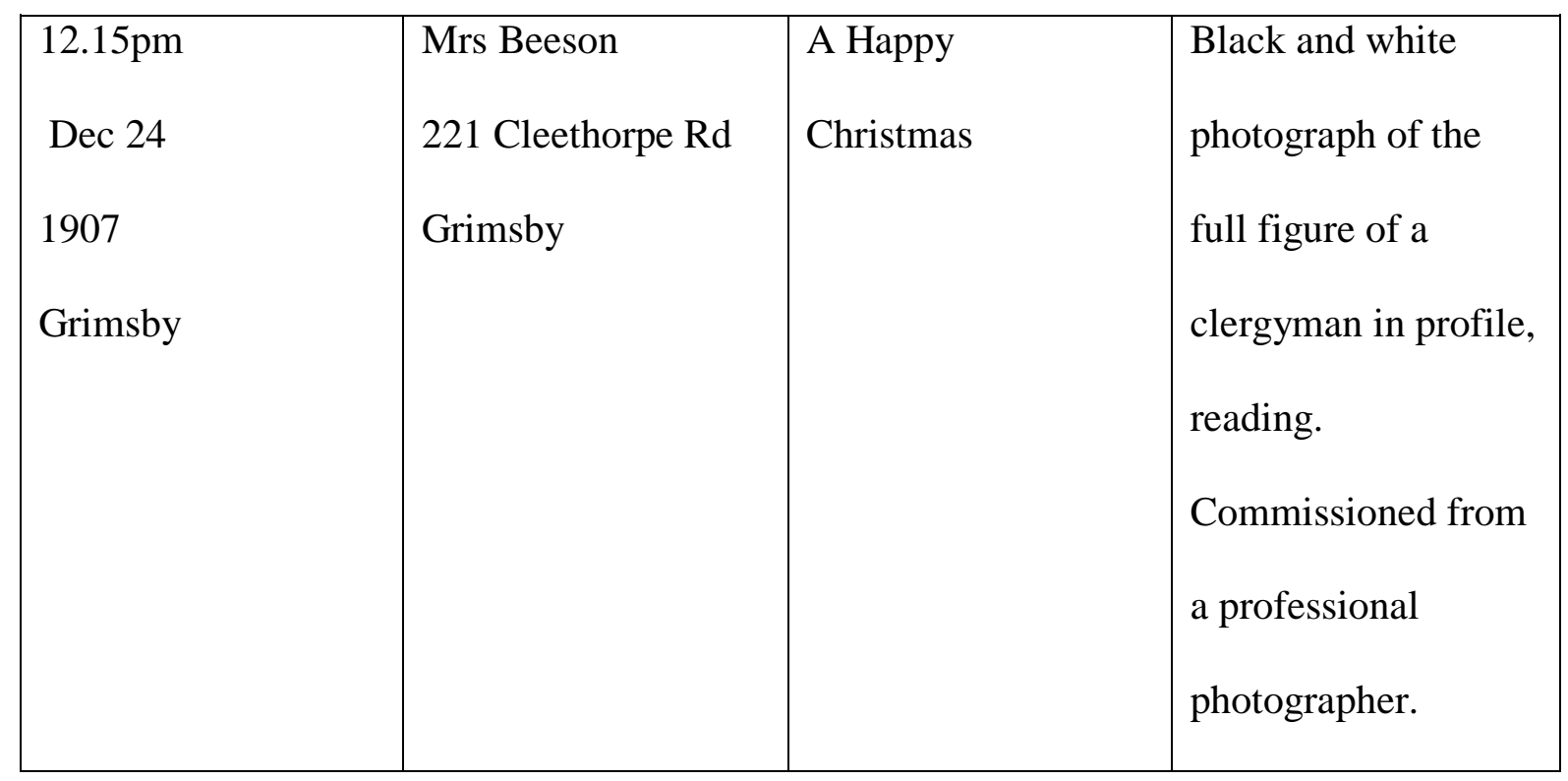

This is a Christmas greeting postcard. Given that the message contained no signature, it is virtually certain that the person depicted in the photograph sent the card as otherwise the sender would remain anonymous. Our collection includes other examples of clergymen, who have commissioned professional photographers to produce postcards. The 3A Folding Pocket Kodak camera of the period was designed to produce photographs in a postcard format, making the commissioning of a card of oneself, family or other desired image easy, on a local basis (Hannavy 2011: 22). Photographers, publishers and other media such as periodicals about postcards proliferated as the postcard phenomenon grew. Although most postcards in our collection were mass produced, there are many which appear to have been privately commissioned, and some handmade by the sender, featuring personalised drawings or paintings.

At the time of receiving the card Mrs Beeson was 41 years old ${ }^{3}$. In the 1901 census Mrs Mariette Beeson had been living at this address. Born in 1866 in Shoreditch, London, 
Mariette was a fruiterer and florist married to Alfred, a rope maker's clerk. In 1901 they had four young children, a servant and a visitor living with them. Ten years later the family was living elsewhere in Grimsby, still with a large household including a nephew, niece and a housekeeper. The eldest daughter, also called Mariette, had become a school mistress and eldest son Alfred an assistant in a rope store. So by Edwardian standards this appears to be an educated, reasonably comfortable, although very likely hard-working family.

The practice of sending Christmas cards was widespread in Britain throughout the twentieth century but this card illustrates that even within that convention practices did change, especially in that rather than a greetings card in an envelope, this is a Christmas postcard. In the digital era, especially as postage has become expensive greetings move increasingly to digital media, sometimes in the form of status updates from one to many ‘friends' or 'followers' in one's network (Page 2012). The brevity of the message and lack of personalisation suggests this was very much a bulk Christmas act i.e. that he has sent many such cards simultaneously, in the afternoon of Christmas Eve. As this was a local card it would have arrived within hours, so much more like the receipt of a digital message then the late twentieth century ‘last posting date before Christmas’ barrier. 


\section{Card 2}
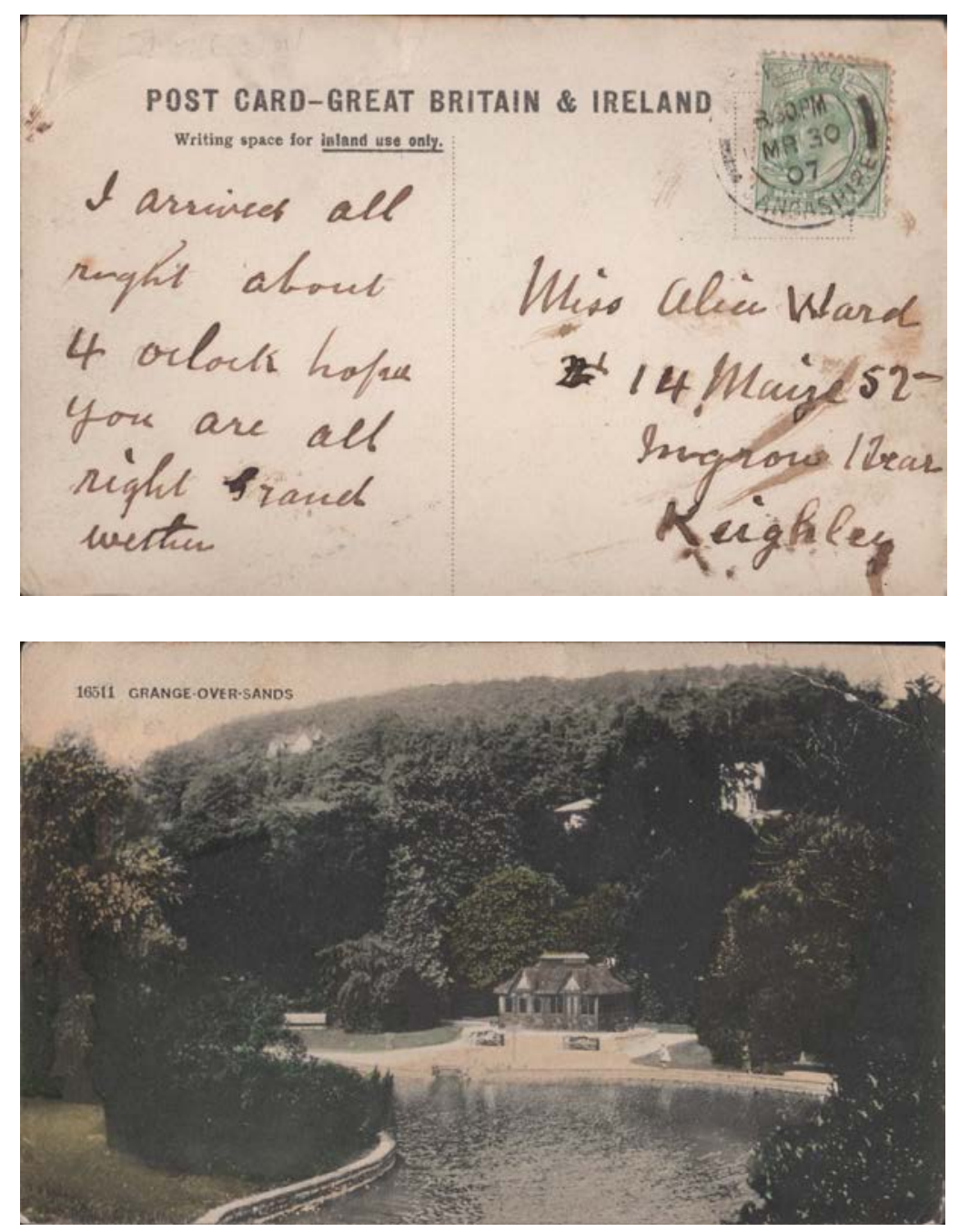

Table 2 Card 2602

\begin{tabular}{|l|l|l|l|}
\hline Postmark & Addressee & Transcript of & Description of \\
message side & picture side \\
\hline $3.30 \mathrm{pm}$ & Miss Alice Ward & I arrived all & Black and white \\
Mar 30 & right about & photograph, tinted \\
1907 & Ingrow Near & 4 oclock hope & with green on trees \\
\hline
\end{tabular}




\begin{tabular}{|l|l|l|l|}
\hline & Keighley & $\begin{array}{l}\text { you are all } \\
\text { right grand } \\
\text { weather }\end{array}$ & caption top left \\
'16511 Grange-over- \\
Sands'. Image is of a \\
boating lake, with a \\
small pavilion on far \\
\end{tabular}

Looking back at postcards after more than a hundred years, it is easy to assume that many were sent with the function of sending greetings from a holiday, since that was almost the only function for picture postcards that continued into the mid and late twentieth century (see Vincent, 2000 122-3; Malcolm and Becker 2008). A relatively small proportion of cards in our large dataset consists of what are clearly holiday postcards, and perhaps as many are sent to people while they are away on holiday as those sent from holiday destinations. This message does contain three typical topics associated with cards sent by travellers away from home for whatever purpose in our dataset: some information about the sender's travel movements, an expression of good wishes and a remark about the weather.

Miss Alice Ward was 16 at the time of receiving this card, living in the town where she was born. By the time of the 1911 census, four years later, she was working as a 'worsted drawer', that is in textiles, Keighley's most prominent industrial sector, and overall 
in England and Wales the sector that employed about one third of working women (Crow, 1978). Alice's family were all textile workers; father John who had been born in Warwickshire in 1856 was a wool sorter who moved to Yorkshire before marrying. Alice had followed her older sister Caroline into an identical post; younger brother Charles was working as a bobbin sorter. There was a further child at home in 1907, Jesse Wright Ward, just seven years' old. The family lived in four rooms in a terraced house in a tightly packed area of sturdy homes still standing today. I have traced workers living in more cramped conditions, in more poorly paid occupations as receivers of postcards in our collection. Heaton (1896: 5) had declared in a letter to The Times, 'Now the postcard is the letter of the poor.' The postcard cannot have permeated into the very poorest, or transient underclass, but there is certainly evidence it was a common means of communication among the working classes. 


\section{Card 3}
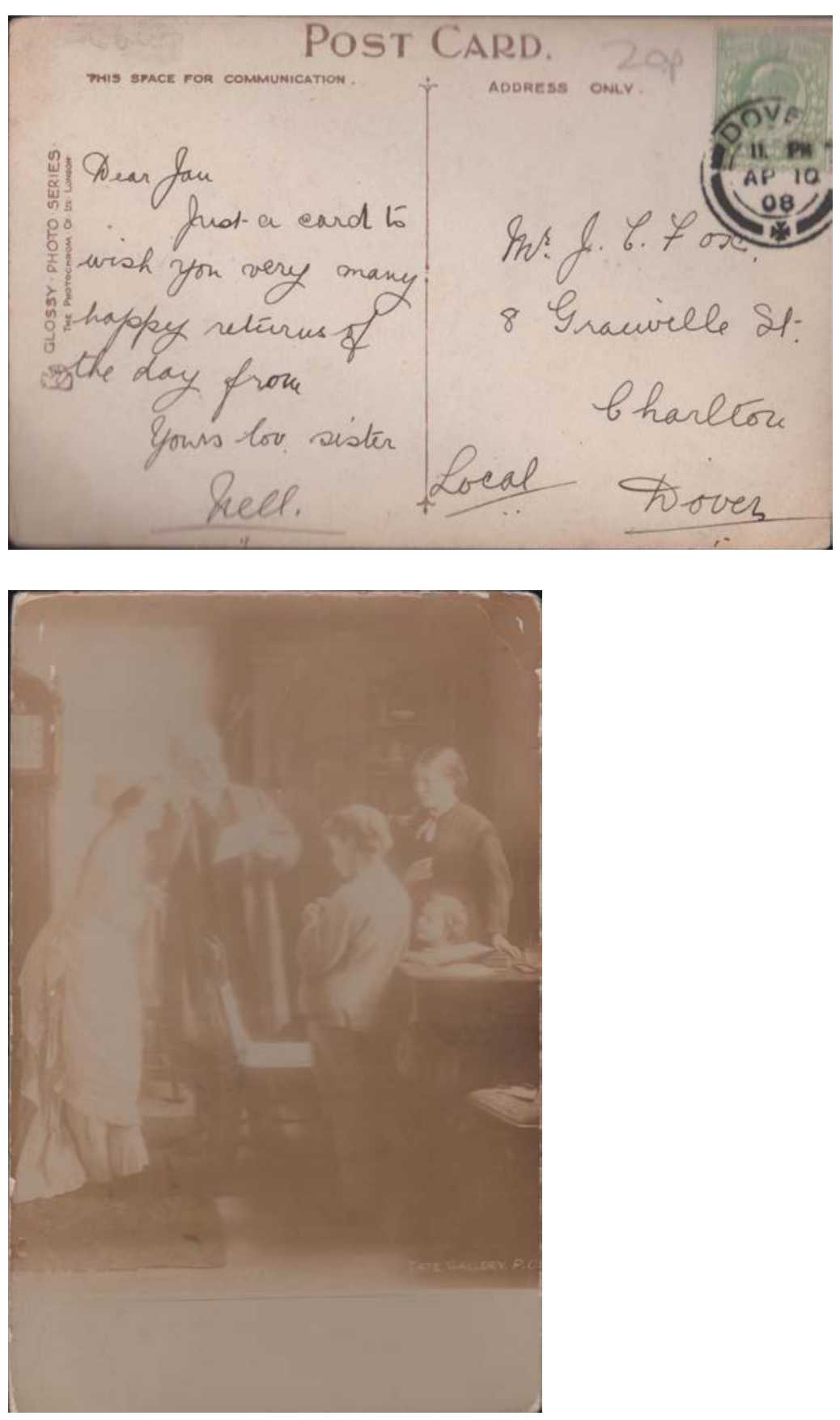

Table 3 Card 2603

\begin{tabular}{|l|l|l|l|}
\hline Postmark & Addressee & Transcript of & Description of \\
& & message side & picture side \\
\hline
\end{tabular}




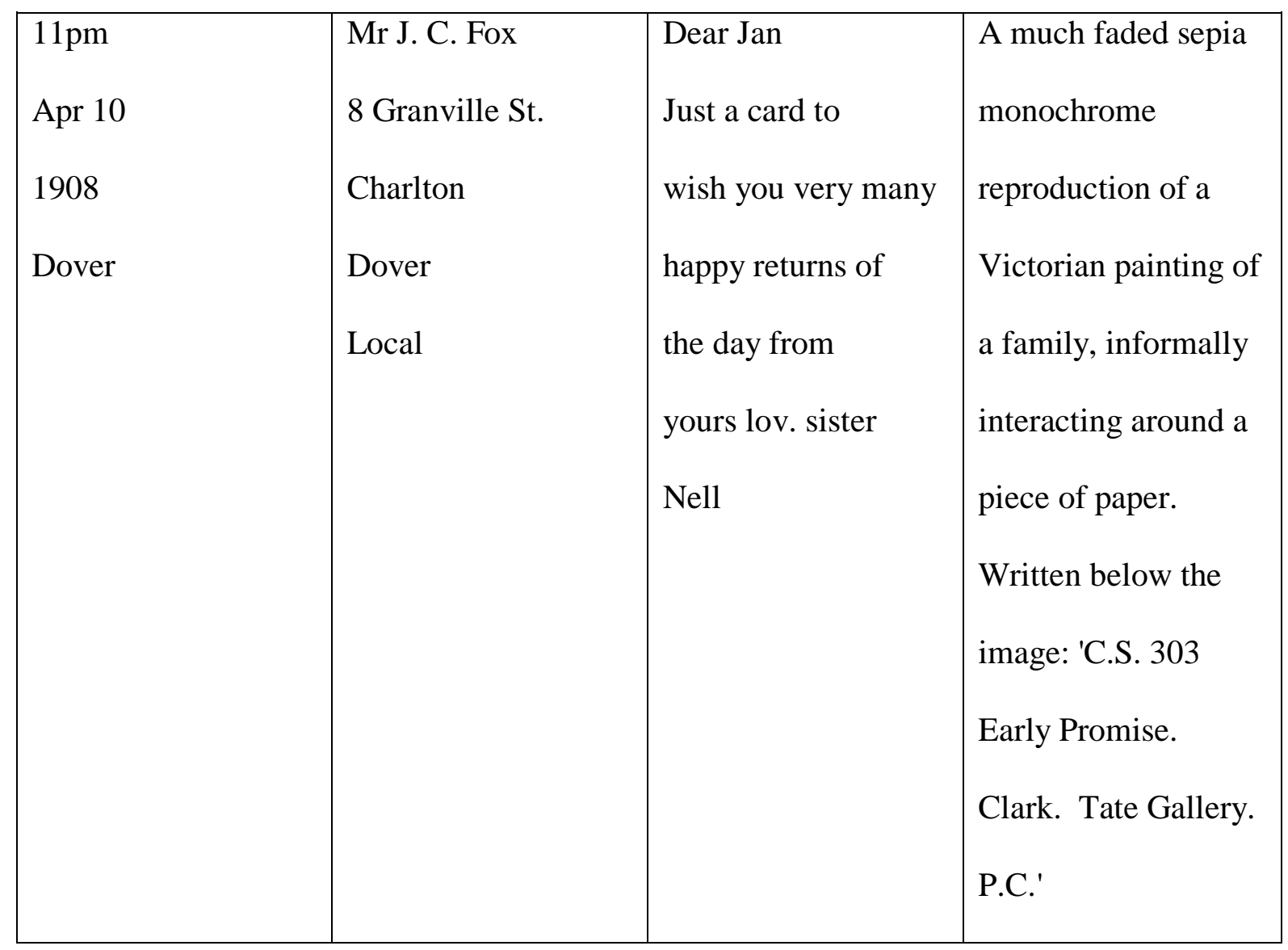

With information gleaned from the 1911 census it can be deduced that this card was sent on the occasion of Mr John Collon Fox's twenty-second birthday by his sister Ellen, known by the common diminutive, Nell. In 1901 the family had all been living together, at 39 Granville Street in Dover. At that time John's father, William, native to the area, was a bread maker; but the idea of straitened circumstances is suggested in that the family also had two boarders living with them. John's mother, Elizabeth, had been born in Exeter and was already forty years' old when John was born, the fourth out of her five children. Nell worked as a dressmaker and John a timber merchant's clerk. In 1911 William gave 'billiard marker' as his occupation. This was likely to have been a very low-earning occupation: Leo Tolstoy (to use the contemporary transliteration) immortalised the job in a short story told in the first person: 
Everybody knows it's our business to score. You don't get a chance to get a bite of anything, and you don't get to bed till two o'clock o' nights, but you're always being screamed at to bring the balls. (Tolstoi, 1898np).

The idealised family portrait on the card, a reproduction of a painting by Joseph Clark, must have been different from the family Nell had left. It shows, in an immaculately tidy although small room, an respectable looking father, a still youthful mother and three neatly dressed children. As both the sender and recipient live in the same town, the card has been sent as a greetings card, to send birthday wishes, and so embodies a gift in itself, rather than merely the vehicle for a message. The message is a conventional birthday greeting, with some formality in the salutation and sign-off, carried over from the letter-writing genre, yet may be imagined at least to convey some warmth in the sentiment and abbreviation for 'loving'. The Victorian painting has perhaps been selected as a generally popular image for aesthetic reasons, or perhaps its topic of family alludes to the sibling relationship. 
Card 4
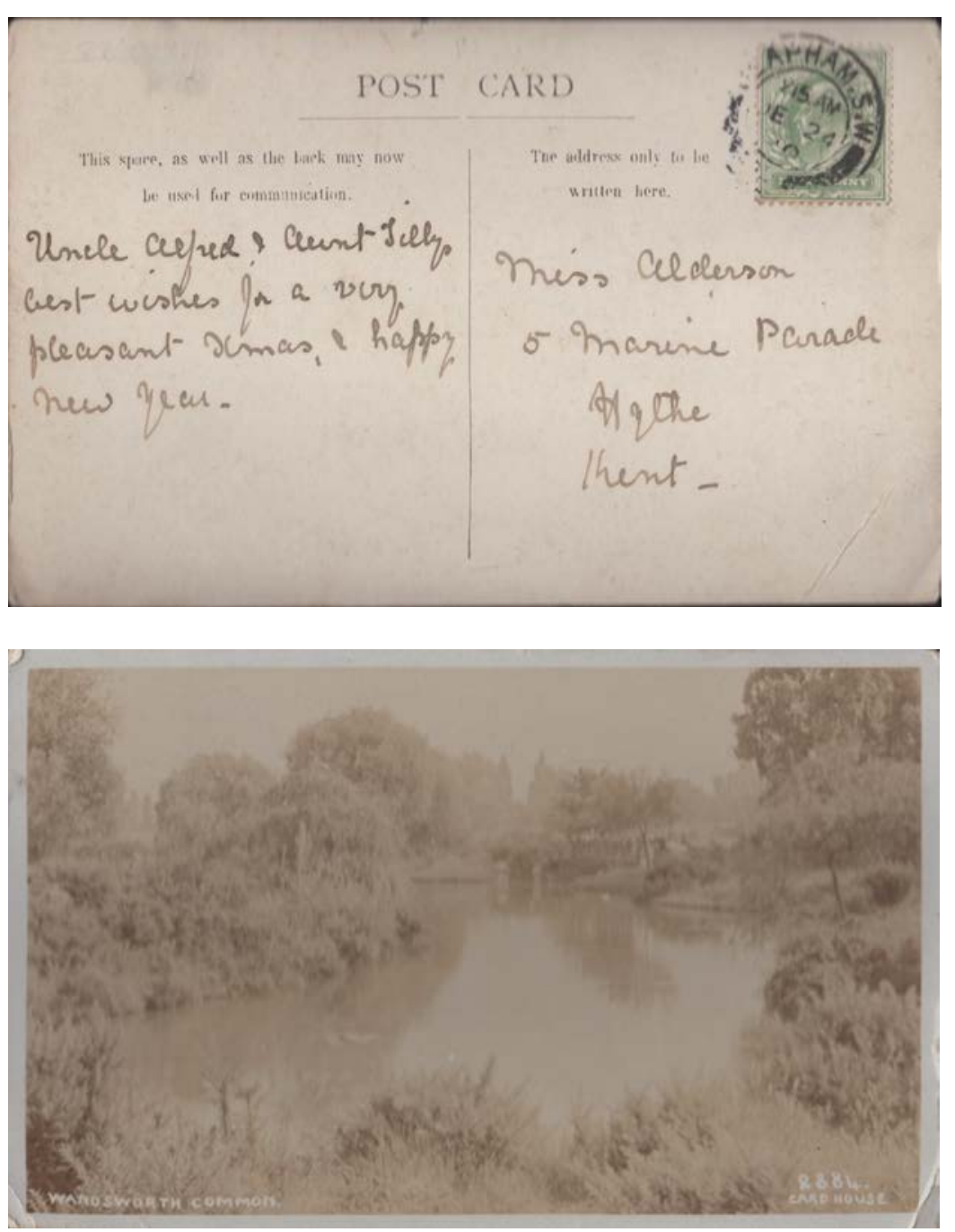

Table 4 Card 2604

\begin{tabular}{|l|l|l|l|}
\hline Postmark & Addressee & Transcript of & Description of \\
& & message side & picture side \\
\hline $2.15 a m$ & Miss Alderson & Uncle Alfred \& & A much faded sepia \\
Dec 24 & 5 Marine Parade & Aunt Lilly & image of a \\
1910 & Hythe & & photograph of a \\
\hline
\end{tabular}




\begin{tabular}{|l|l|l|l|}
\hline Clapham, SW & Kent & best wishes for a & small lake with a \\
(London) & very & small footbridge in \\
pleasant Xmas, \& & the distance. \\
happy & new year. & 'Wandsworth \\
& & & Common. 2884. \\
& & & Card House.' \\
\hline
\end{tabular}

Miss Alderson, 21 years old, living with her widowed mother, was keeping a ten-roomed boarding house. Alfred and Lilly were probably staying there for their Christmas holiday. The sending of a greeting is a writing practice, making use of ritualised phrases. Qualities of writtenness such as attention to layout and legibility cement the sense of the communication as a gift, and so essential is the identification of a sender. Yet with this kind of communication the sender has no need to identify her or himself by name; apart from the salutation of 'uncle' and 'aunt' the handwriting of individuals can become recognisable and familiar, even seeming to convey something of a writer's personality (Hensher, 2012).

This is the second Christmas postcard of this small sample. Although there were many specifically Christmas designs available, many people preferred their own choice of theme, as seen in card 1 and confirmed by Rogan's collection (2005: 7). The sender has chosen an image from her or his locality, depicting an almost rural scene in suburban London. It illustrates the usefulness of the postcard as a means of communication to and from people who are mobile, away from home. Many postcards in our collection are sent to people 
staying in boarding houses, hotels, or while visiting others; this is sometimes but not always indicated through the use of the convention 'c/o' (short for 'care of'). Postcards when sent as gifts often convey some sense of pleasure with their choice of image. Here, the just visible house and little footbridge with people on it suggest a scene for leisure, perhaps weekend walks. 


\section{Card 5}
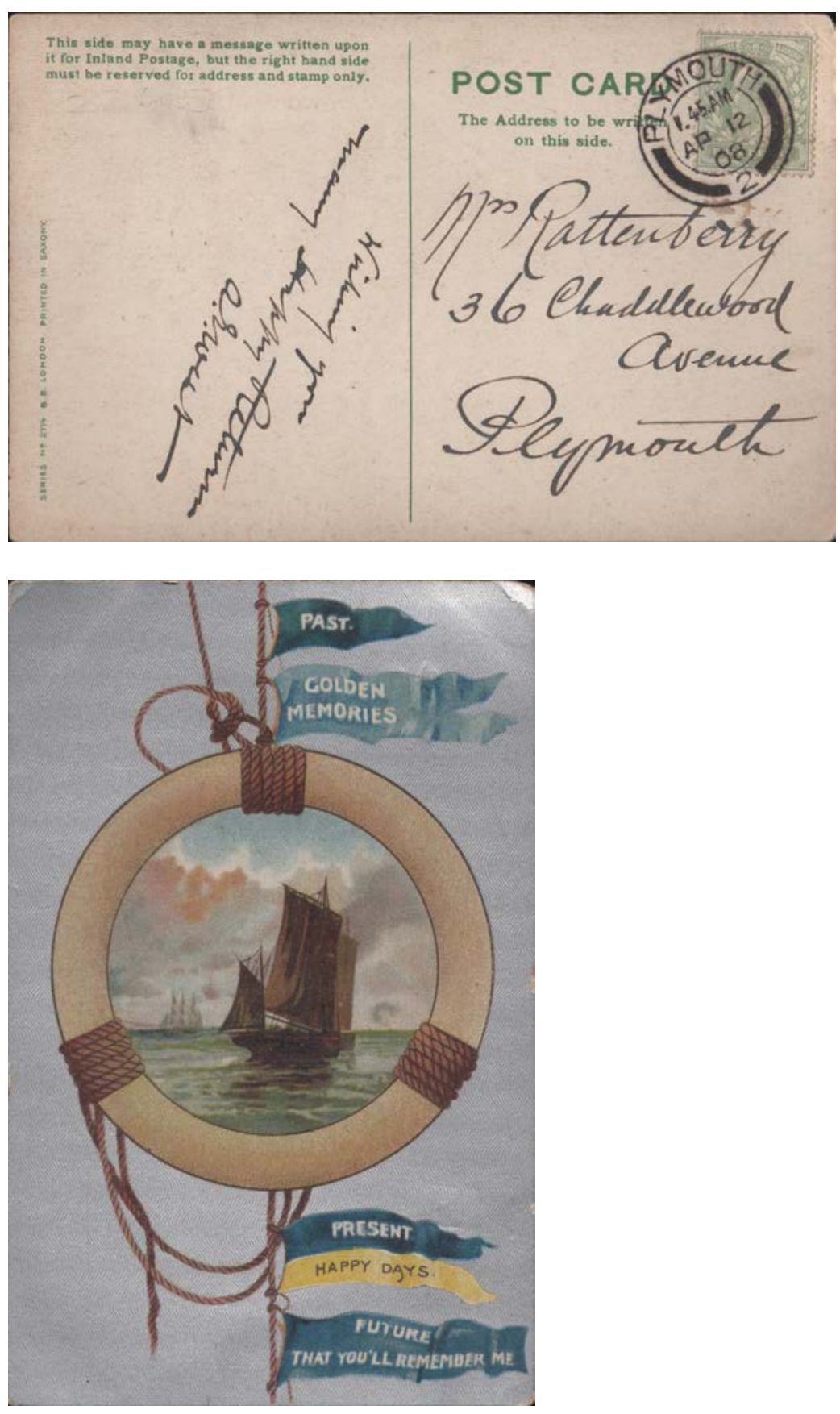

Table 5 Card 2605

\begin{tabular}{|l|l|l|l|}
\hline Postmark & Addressee & Transcript of & Description of \\
& & message side & picture side \\
\hline
\end{tabular}




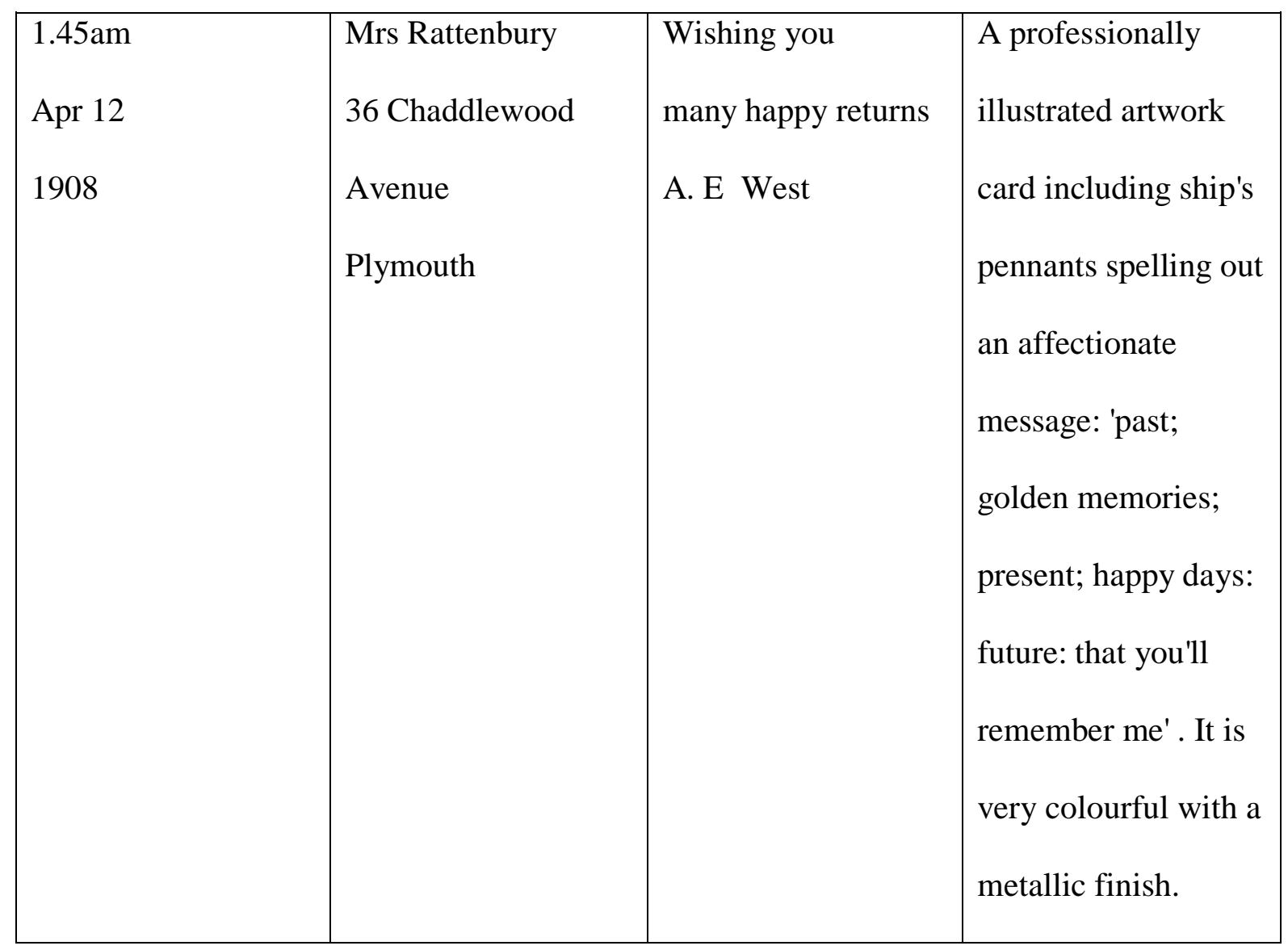

This elaborate birthday postcard, with relatively high production values in comparison with most of our collection, was sent to Mrs Elizabeth Rattenbury. She was living in a fiveroomed house with her husband John, a gentleman servant, and their three children. (The counting of the five rooms would not have included functional areas such as a scullery, landing, lobby, closet and bathrooms.) The oldest, although twenty years old in 1911, was described as 'at home' in lieu of an occupation; her sister was a dressmaker, Elizabeth's former occupation. The youngest child, Leslie, was 8 years' old. There are two people called A.E. West recorded in the 1911 census in Plymouth, so one of them sent this as a $45^{\text {th }}$ birthday card. 
- Alfred E West, 37 Penrose St, aged 15 in 1908, living with his family, an 'assistant daily paper'

- Alfred Edward West, 14 Beaumont Road, (aged 39 in 1908) a boarder, living with the Findlay family, a chemist assistant.

Card 5's sender might then have been a fifteen year old boy, but this was an unusual demographic for postcard writing, judging from our collection. There might be a clue in the 1901 census in that it had included a 24-year-old boarder of the Rattenburys, Walter Maddicks, who worked on the railway. So it is perhaps more likely that the chemist's assistant was a friend or had even boarded himself temporarily with the Rattenbury family.

The message is extremely short, a conventional greeting; and the sender has identified himself in a somewhat formal way - two initials and a surname. This card would have been relatively expensive to buy; having been carefully designed and produced by a postcard publisher. Its nautical theme was designed to be resonant in the maritime city of Plymouth, the location of its sending and receipt; perhaps its sender knew that Elizabeth was the daughter of a ship broker. 


\section{Card 6}
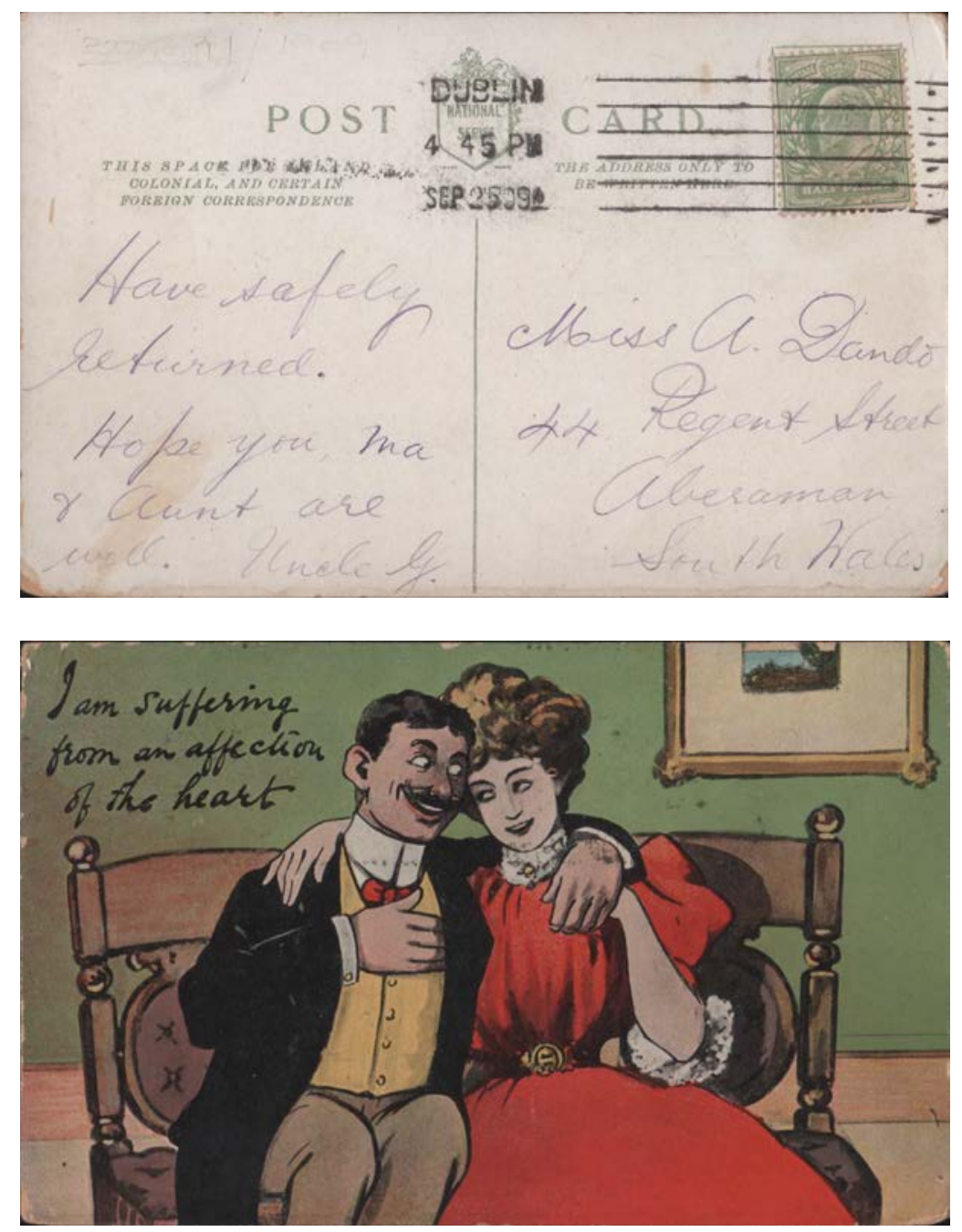

Table 6 Card 2606

\begin{tabular}{|l|l|l|l|}
\hline Postmark & Addressee & Transcript of & Description of \\
& message side & picture side \\
\hline $4.45 \mathrm{pm}$ & Miss A Dando & Have safely & Drawn \\
Sep 25 & 44 Regent Street & returned. & professionally for \\
1909 & Aberaman & Hope you, Ma & postcard publisher. \\
\hline
\end{tabular}




\begin{tabular}{|l|l|l|l|}
\hline Dublin & South Wales & \& Aunt are & $\begin{array}{l}\text { Comic style, slightly } \\
\text { caricatured image of } \\
\text { couple sitting on }\end{array}$ \\
& & & $\begin{array}{l}\text { lounge in an } \\
\text { embrace. In } \\
\text { handwritten style }\end{array}$ \\
& & & font caption 'I am \\
& & & suffering from an \\
affection of the heart'
\end{tabular}

Card 6 demonstrates two incomplete sentences, an omission of the first person subject that appears to be a socially acceptable adaptation to the spatial constraints of a postcard, remaining perfectly understandable to its reader. On first reading of the message (see figure 2), the message seems simple to interpret. In writing of his 'return', on a card sent from Dublin to South Wales, the implication would seem to be that an uncle has been visiting his niece. He now writes to say he is home again and to send good wishes to her and two other female relatives (presumably of both). The message then appears relatively trite. Through looking at the picture side (see figure 3) one would assume that part of the point of sending the card is to give pleasure by sending a humorous card with a near-pun: (affection for affliction) and a slightly risqué illustration. But evidence from historical records leads to a very different interpretation of card 6 from that obtainable through text analysis alone. 
The 1911 census shows Annie Morris Dando living at the address on the card. She was then a 19 year old student. Annie was living with her widowed mother, Elizabeth, sixty years old , Elizabeth’s sister, a widowed dressmaker named Agnes Ann Jennings, and their brother, Samuel Thomas Taylor, a wagon painter. Ten years earlier the residents of the house had also included Annie's father, William, a coal miner hewer. William died in the third quarter of 1909 , the very period this card was sent. So the card writer had very likely returned from visiting the family around the time of the death, perhaps for the funeral. With this knowledge, the simple conventional message takes on a deeper hue. Presumably the writer is conveying that he is still thinking of the family going through such a difficult time (Wall 2007). The selection of the humorous card, with its near-pun, becomes a deliberate act to cheer the bereaved daughter, the youngest in the household. He is referring to the relatives as they stand to Annie rather than himself. From the census records it appears that neither Elizabeth nor William had a brother who could be this person; the 'uncle' may be honorary. 


\section{Card 7}
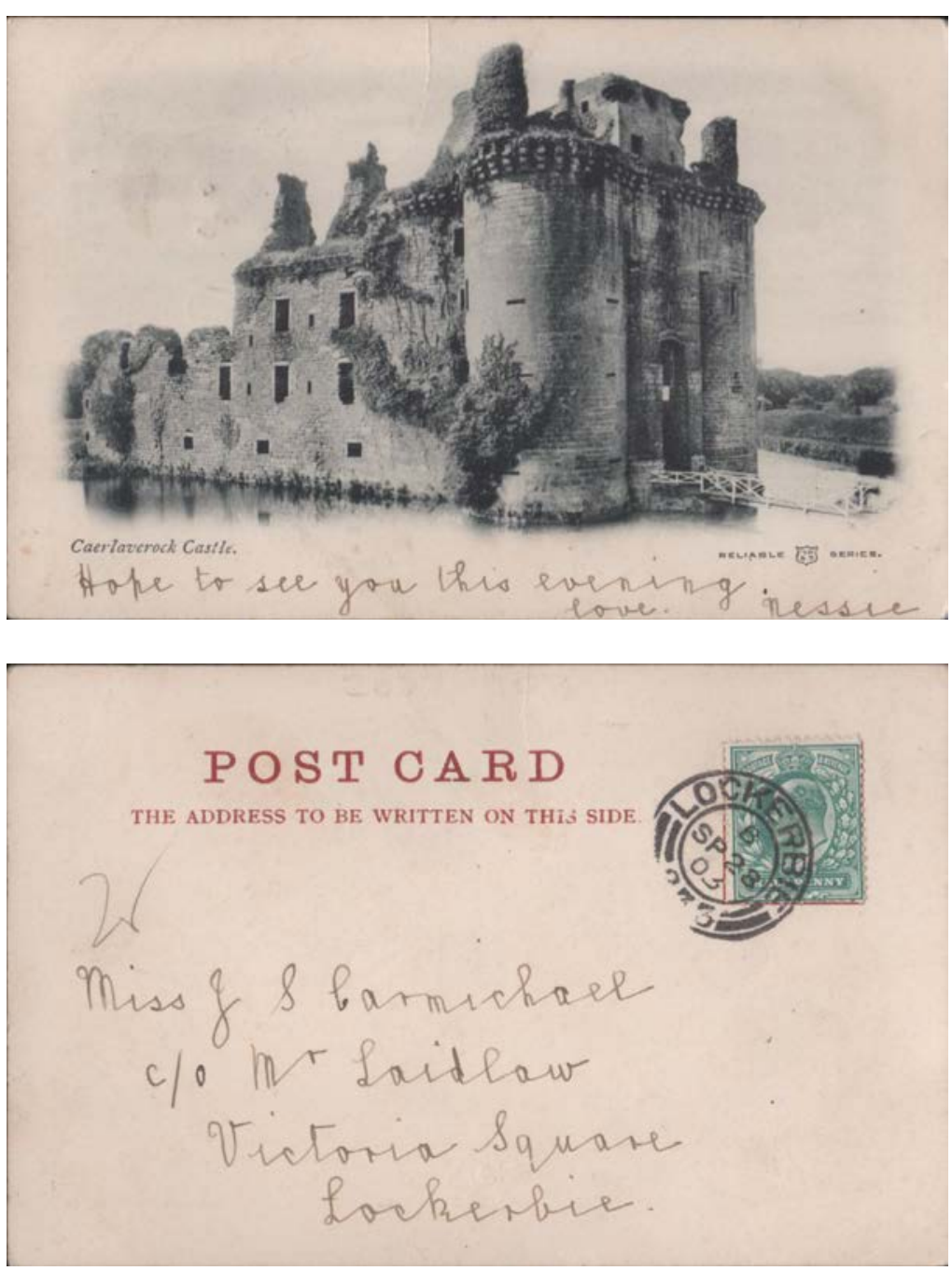

Table 7 Card 2607

\begin{tabular}{|l|l|l|l|}
\hline Postmark & Addressee & Transcript of & Description of \\
& & message side & picture side \\
\hline B & Miss J S Carmichael & & monochrome image \\
& & & captioned \\
\hline
\end{tabular}




\begin{tabular}{|l|l|l|l|}
\hline 1903 & $\begin{array}{l}\text { C/O Mr Laidlow } \\
\text { Lockerbie }\end{array}$ & Victoria Square & \\
& Lockerbie & & $\begin{array}{l}\text { 'Caerlaverock Castle. } \\
\text { Reliable WP\&S } \\
\text { series.' message: } \\
\text { Hope to see you this } \\
\text { evening } \\
\end{array}$ \\
& & love Nessie \\
\hline
\end{tabular}

This card is an example of the turn-of-the-century format as explained above, that permitted the writing of a brief message in the margin of the picture. This card, with its reference to a planned meeting on the very same day, makes it clear how people could take for granted the existence of several deliveries a day in towns, so that it was possible to send a message knowing it would arrive a matter of hours later.

Nineteen cards in our collection were sent to this Miss J S Carmichael. Her correspondents sometimes referred to her postcard collecting hobby. It is because such collections were often kept in albums, later broken up when in the hands of dealers before we acquire the cards, that our collection unintentionally includes several cards sent to a single individual. With the aid of these cards and a variety of records a considerable amount of information about her can be synthesised into a short biography.

Janet Stewart Carmichael was born in 1888, the daughter of a surgeon who died within three years. The 1891 census listed Janet Carmichael, then aged 3, as living with her mother, grandmother, and a servant at 1085, Chester Road, Stretford. In her early years Janet 
made a friend with whom she later swapped postcards and gossip, about trips, figures in popular culture and literature. By the time of the 1901 census Mrs Carmichael and her daughter had moved to 2 The Hollies, Fairfield, Buxton. Although Mrs Carmichael told the census enumerator she was 'living on her own means', a local commercial directory shows that she was actually doing the same as her neighbour at The Hollies, letting out rooms. Janet Carmichael occasionally travelled to Scotland; it seems to visit connections of her father. As was usual at the time, she received as well as sent postcards while she was away. Janet's network of postcard correspondents was distributed over a considerable distance; possibly her mother's lodgers resulted in some of these connections. Some cards refer to seemingly minor health issues, although one in 1908 referred to Janet being unable to sit an exam owing to illness. A high proportion of the cards in our large dataset make reference to health and illness; an indication of how before modern medical advances health was considerably more precarious than today. Janet Carmichael died aged 23 in 1911, appreciated in the local newspaper as a popular Sunday school teacher. 


\section{Card 8}
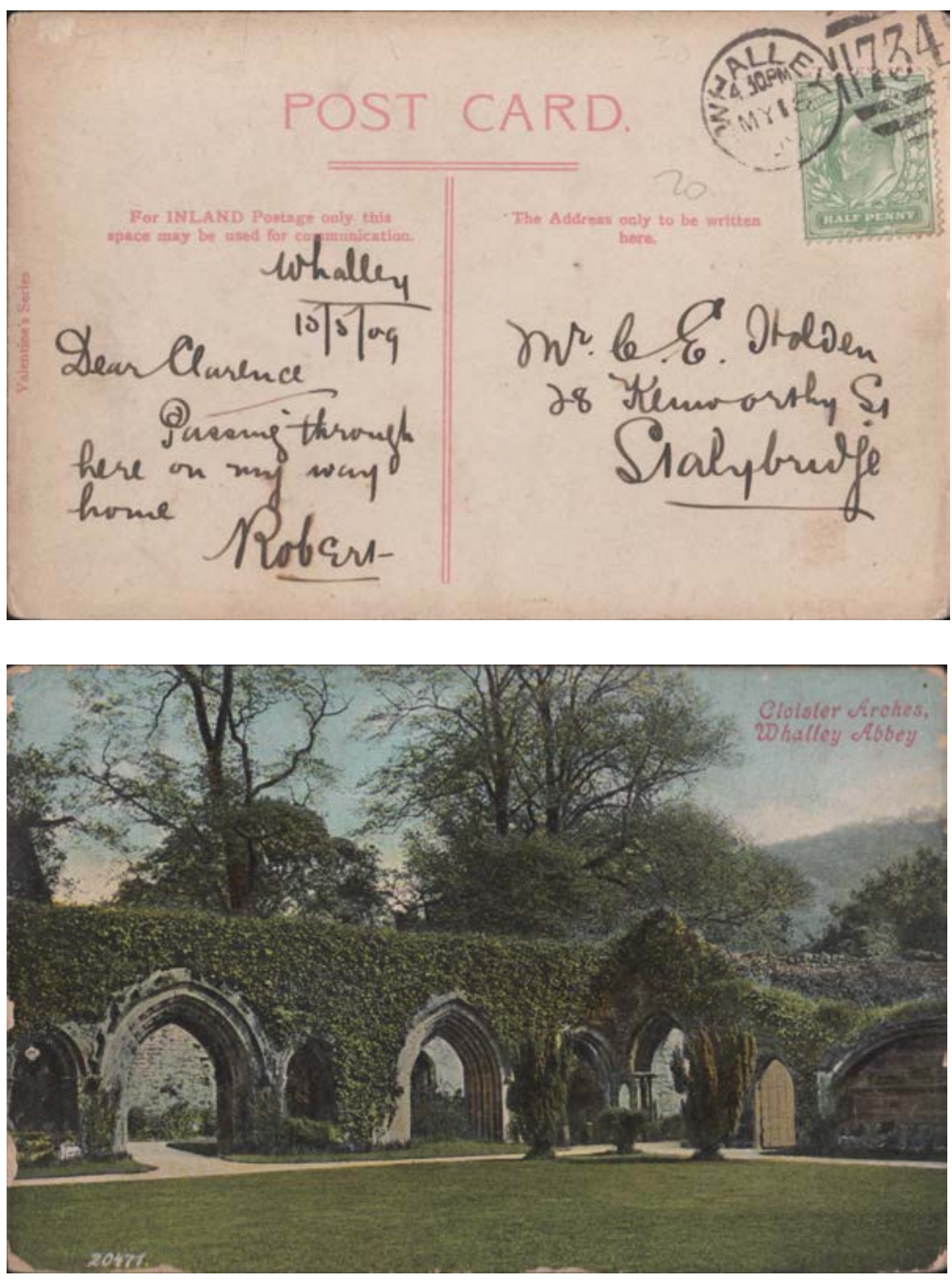

Table 8 Card 2608

\begin{tabular}{|l|l|l|l|}
\hline Postmark & Addressee & Transcript of & Description of \\
& & message side & picture side \\
\hline $4.30 \mathrm{pm}$ & Mr. C. E. Holden & Whalley & A photograph with \\
May 15 & 28 Kenworthy St & $15 / 5 / 09$ & additional green \\
1909 & Stalybridge & Dear Clarence & tinting of a foliage \\
\hline
\end{tabular}




\begin{tabular}{|l|l|l|l|}
\hline Whalley & & $\begin{array}{l}\text { Passing through } \\
\text { additional postmark: }\end{array}$ & here on my way \\
home & Robert & grass in front and \\
trees behind. \\
Captioned top right \\
\end{tabular}

In the 1911 census there is a Clarence Edgar Holden living at the address on card 8 with his wife and two children. He is 38, born 1873 in Stalybridge. Originally working from a young age as a spinning room hand, by 1901 he had turned his hand to the relatively modern trade of insurance agent. Described (very likely by himself) in the slightly grander term of 'Life Assurance Agent' in 1911, he was very probably doing a considerable amount of travelling by train in the course of his work. Rogan (2005:9) quotes an account of a rail traveller in 1900: 'Your fellow travellers never speak. They have little piles of picture postcards on the seat beside them, and they write monotonously.' Perhaps Robert and Clarence both exhibited similar modern lifestyles and methods for keeping in touch.

Whalley Abbey, today as now, is a fairly well known tourist attraction and beauty spot, being the well-preserved ruins of a fourteenth-century Cistercian Abbey. We have other very similar views of Whalley Abbey in the collection; the 'standardized repertoires' of postcard images an essential element of their cultural significance (McQuire, 2008: 45). This card is of interest in its ways of making deictic reference to the location of the sender. Robert refers to 'here' - given that this is a topographical card, he can be read as communicating 
through reference to the picture side of the card a specific location. At pains to communicate the dynamic aspect of his movement; in terms of his authored message, he is 'passing through’ Whalley (Abbey).

\section{Card 9}
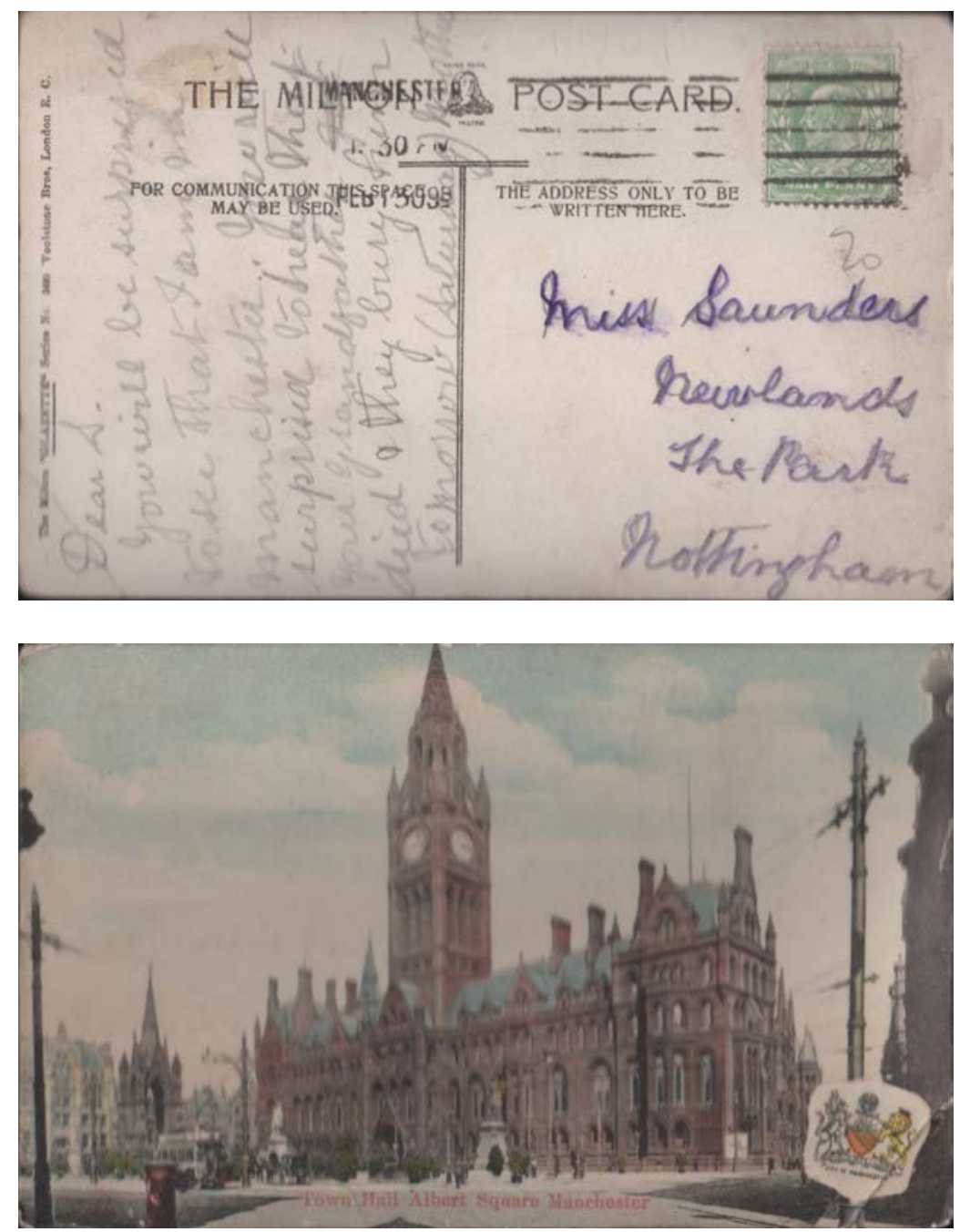

Table 9 Card 2609 


\begin{tabular}{|c|c|c|c|}
\hline Postmark & Addressee & $\begin{array}{l}\text { Transcript of } \\
\text { message side }\end{array}$ & $\begin{array}{l}\text { Description of } \\
\text { picture side }\end{array}$ \\
\hline $\begin{array}{l}\text { 1.30pm } \\
\text { Feb } 13 \\
1909 \\
\text { Manchester }\end{array}$ & $\begin{array}{l}\text { Miss Saunders } \\
\text { Newlands } \\
\text { The Park } \\
\text { Nottingham }\end{array}$ & $\begin{array}{l}\text { Dear S. } \\
\text { You will be } \\
\text { surprised } \\
\text { to see that I am in } \\
\text { Manchester. You } \\
\text { will } \\
\text { surprised to hear that } \\
\text { your grandfather } \\
\text { died \& they bury } \\
\text { him } \\
\text { tomorrow (Saturday) } \\
\text { Mother }\end{array}$ & $\begin{array}{l}\text { Colour image, } \\
\text { possibly a } \\
\text { photograph with } \\
\text { hand tinted additions } \\
\text { of colour of an urban } \\
\text { scene, without } \\
\text { people, and a 'City } \\
\text { of Manchester' logo } \\
\text { superimposed } \\
\text { bottom right. } \\
\text { Captioned at bottom } \\
\text { 'Town Hall, Albert } \\
\text { Square Manchester.' } \\
\text { small. } \\
\text { In front of the } \\
\text { building, partially } \\
\text { hidden by a } \\
\text { boregrounded letter }\end{array}$ \\
\hline
\end{tabular}


This is the most overtly dramatic message among these 10 cards. A mother writes hurriedly to her daughter in pencil, telling her of her grandfather's death and the impending funeral. We cannot know if the recipient had the resources to leave and get to the funeral, but the speed of the delivery meant that it may have been a possibility in terms of time. That the writing was extremely hurried is suggested by the presence of a word, then obliterated, before the word 'died' is selected and the non-standard syntax 'will surprised' for 'will be surprised' and 'they bury him' for 'they will bury him'. In addition the address has been written in pencil, but evidently the mother feared it might not be clear enough, or perhaps become obliterated, through damp for example, so she then went over it with indelible pencil. This is indicative of her attention to the role of the Post Office in transporting this communication. But she did not try to overwrite the message. The message begins not with the news of the death but rather the apparently surprising announcement that the writer is in Manchester, the emphasis of that topic presumably underlined through the selection of a Manchester scene postcard.

Alone among this sample it has not been possible to definitively identify either the addressee or her mother through public records. 


\section{Card 10}
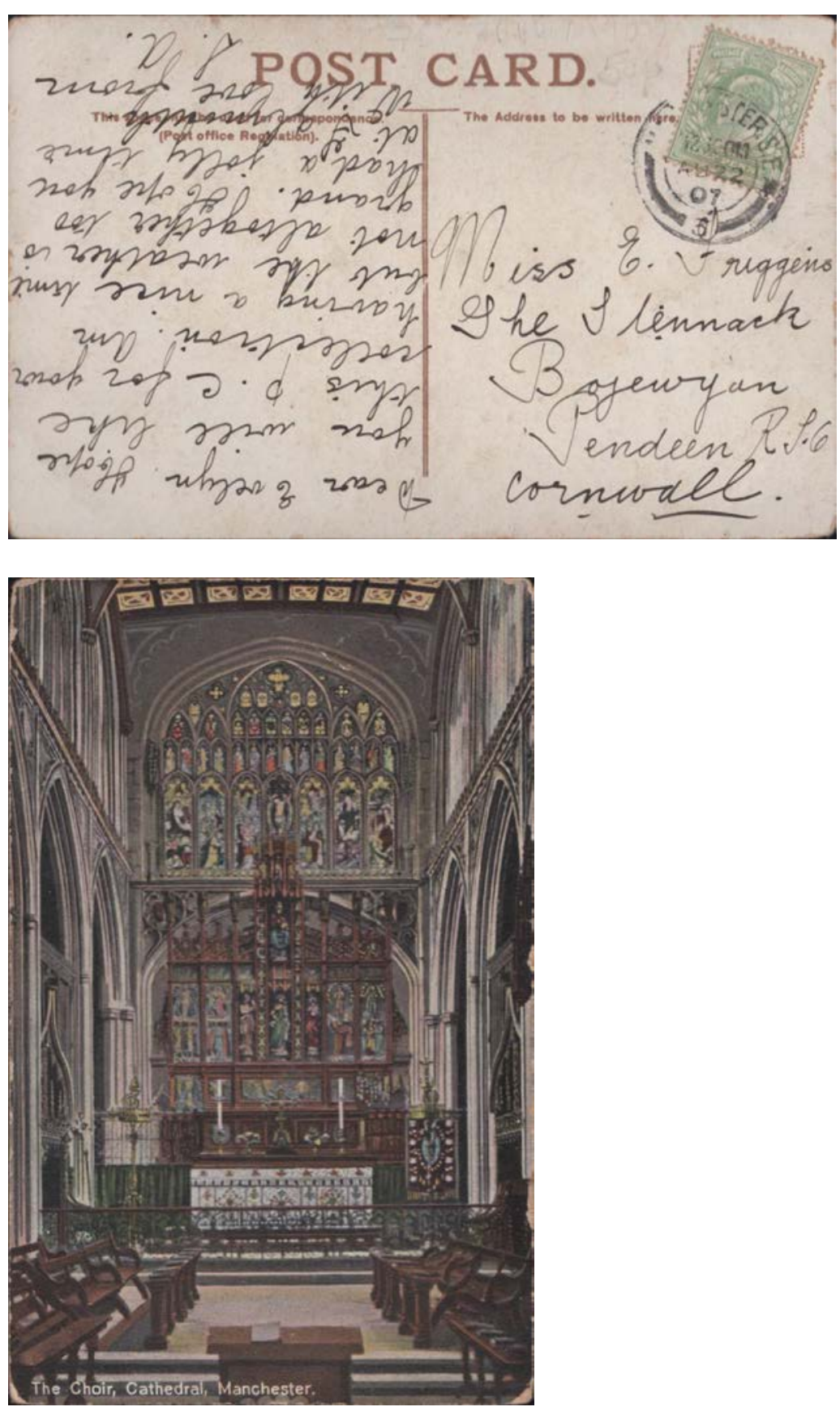

Table 10 


\begin{tabular}{|c|c|c|c|}
\hline Postmark & Addressee & $\begin{array}{l}\text { Transcript of } \\
\text { message side }\end{array}$ & $\begin{array}{l}\text { Description of } \\
\text { picture side }\end{array}$ \\
\hline $\begin{array}{l}\text { 12.30pm } \\
\text { Aug } 22 \\
1907 \\
\text { Manchester } \\
\text { S.E. }\end{array}$ & $\begin{array}{l}\text { Miss E. F. Higgins } \\
\text { The Slennack } \\
\text { Boyewyan } \\
\text { Pendden R.S.C. } \\
\text { Cornwall }\end{array}$ & $\begin{array}{l}\text { Dear Evelyn } \\
\text { Hope } \\
\text { you will like } \\
\text { this P.C. for your } \\
\text { collection. Am } \\
\text { having a nice time } \\
\text { but the weather is } \\
\text { not altogether too } \\
\text { grand. I hope you } \\
\text { had a jolly time } \\
\text { at Plymouth. } \\
\text { With love from } \\
\text { S.A. }\end{array}$ & $\begin{array}{l}\text { Image of nave with } \\
\text { details, hand- } \\
\text { coloured by } \\
\text { publisher. Captioned } \\
\text { 'The Choir, } \\
\text { Cathedral, } \\
\text { Manchester.' }\end{array}$ \\
\hline
\end{tabular}

This card alludes to the enormously popular hobby of collecting cards in this era, 'a fad amongst the working class’ (Malcolm and Becker 2008: 59). The image of Manchester Cathedral features elaborate use of intricate colour in the depiction of the nave, altar, altarpiece and stained glass windows behind and it may be that this sophistication contributes to what the sender perceives as the desirability of the card. 
Evelyn Annie Friggens was the daughter of a tin miner living in the environs of Bojewyan, a Cornish hamlet. She was born in 1890, the second child of Frederick (misspelt as Fedrick in the 1901 census), a tin miner and his wife Prudence. In the 1901 census the Friggens family included 5 children, another was born shortly afterwards. Evelyn died, aged 19, in the second quarter of 1909; the rest of the family were still living very locally in 1911. The 'jolly time' in Falmouth might have been a rare holiday trip, and the postcard of Manchester cathedral likely to have been an image of an exotic location she was unlikely ever to have visited herself.

\section{Discussion}

I now return to the two research questions posed earlier.

1. What writing practices were involved in communicating with Edwardian postcards, as revealed through historical investigations?

2. What meaning-making practices can be revealed through examination of the cards as multimodal texts?

In response to the first research question, it has been shown that people used postcards for varied purposes in their vernacular literacy practices. Cards were popular and convenient to send and did not necessarily require a long message. The content of the message was more diverse than the conventionalised greeting card and holiday postcard genres; see for example the message about the grandfather's death, written possibly in a state of some shock. 
That cards such as 4 and 7 were sent to people while on holiday rather than, as later in the twentieth century, only sent back from holiday-makers, shows how communications by postcard continued between parties regardless of changes in physical location, very much like vernacular digital communications such as SMS (text-messaging) today. In the Edwardian era, cards could be bought, written and posted in far more places than today, while on board trains for example (Staff, 1979). They were indicative of a society that felt itself to be modern in its mobilities in multiple senses: of physical movements for business and leisure reasons, and as users of mobile technologies (Urry 2007).

When on sale the postcards were commodities, bought for various purposes; see for example the death and funeral announcement on card 9. But, as strongly shown by several of the cards, they could be appropriated to form gifts through social interaction, (Jaffe 1999). The act of selecting an appropriate card for the recipient and sending it, whether to function explicitly as a greeting card, or as an addition to a collection, or even to cheer someone after bereavement, contributes to the mutual sense of maintaining relationships between writer and receiver.

In response to the second question, it can be seen that clearly the multimodality of the cards, the writtenness of the text as well as the interrelationship between the written message and the image and writing, contributed salient elements of the communication. As later readers, we are unable to enquire directly as what connection the writer intended to convey between the image and message, nor whether the receiver made any such connection, methods open now to investigators of contemporary digital communications (Androutsopoulos 2008). It can be inferred that a strong connection is intended when the card functions in a greeting capacity (Jaffe 1999; Rogan 2005). And it is at the least very likely 
that the multimodal combination was intended and did have some effect on the recipients see for example the beginning of card 9 in which the sender appears to assume that her daughter will discern she is in Manchester from the image (and postmark), or card 8 where Robert deictically refers to 'here' in the knowledge that can be interpreted through the image (and postmark indeed). Also, as with greeting cards today in the twentieth century and later, as well as digital communications that include photographs or other images, the choice of images can convey a particular stance towards the addressee (Barton and Lee 2013). It does seem likely that the relative sophistication of cards 5 and 10 contributed to their impact; the sender of 10 implied this; the Plymouth sender of 5 appears to allow the picture side to convey, in effect, his message; the multimodal affordances of the cards can be deployed in diverse ways.

In the ‘digital age’, claim Gee and Hayes (2011: 1): 'multimodality is more pervasive, diverse and important today than ever before.' This idea has an immediate appeal, in the form that Gee and Hayes expound, suggesting that a typical text book of the 1950s has fewer colour images than that of today, and that furthermore the textbook may have an online version perhaps with moving image and sound in the form of video. This is indisputable. But nonetheless objections can be raised. First, language is always multimodal. It always has material form, acoustically when spoken, gestured through a sign language, or through specific media when written down (Bickerton, 2003). Written language cannot exist without orthography, layout and the artifacts involved in its creation (Blommaert, 2005; Sebba, 2007). Black text on white paper does not escape multimodality; even if familiarity with certain material forms renders those seemingly transparent, so that we think of the message and little or not at all about the medium (Hall, 1999: 83). If all communication is multimodal, then logically the idea of having more or less multimodality becomes problematic. Further, it 
could be argued that the assertion that multimodality is somehow increased in the digital age rests on taking a convenient example, rather than, say, the contrast between an actual Edwardian postcard and the format of this piece of writing in an academic journal over a century later, whether viewed in print or online.

The examination of these few cards also makes it possible to confront another claim sometimes made for the digital domain that they are in some way between speech and writing, or can be characterised as a blur between the two (Baron 1998; Crystal 2006; Baym 2010). This conflation of mode with any linguistic characteristic is to ignore how writers draw upon a complex range of repertoires (Blommaert, this volume). Cards 1, 3 and 4, for example draw upon knowledge of conventions of written messages sent at the time of special occasions such as birthdays and Christmas. Card 7 's 'Hope to see you this evening love Nessie' reveals that brevity, informality and temporality possibly experienced as close to synchronicity could be combined as features of the Edwardian postcard - as indeed discerned in the popular media of the time. These are not then necessarily the innovative qualities of writing in digital communications sometimes claimed (Baron, 1998; Crystal 2006). It is vitally important to consider the affordances of any means of communication (Lee 2007; Seargeant, Tagg and Ngampamuan 2012). Over-generalising the presence of certain clusters of features in some samples, regarded as prototypical by the interpreter can be remedied by careful attention to the various, analytically separable features that can be used to investigate genre (Biber 1998; Gillen forthcoming).

The very act of sending a greetings card instantiates at the same time a sense of distance between the correspondents, yet an affective act of crossing it. Card 9 has a very different sense of bridging distance; the writer articulates her sense of imagining the surprise, 
even shock of the addressee when receiving this message across time and space. Writing of various conceptions of presence in computer-mediated communication, Lombard and Ditton (1997, unpaged) distinguish ‘presence as transportation’ as one vital meaning, communicated vividly here. In sending his card of Whalley, Robert seeks a momentary occupation with Clarence of 'a shared virtual space that is different from any of the individuals' "real" environments' (Lombard and Ditton, $1997 \mathrm{np}$ ) in the acts of thinking, writing and sending card 8. For Nessie and very likely Janet who saw fit to preserve it, card 7 seems to be a brief written way of bridging a short temporal gap between meetings, when presumably face to face talk will continue the chain of communications; this card instantiates the sense of presence that Milne (2000) identifies across technologies as diverse as the early postcard and email.

\section{CONCLUSIONS}

Finally I suggest three broad themes that emerge from this study of the Edwardian postcard that can also be applied to studies of contemporary writing practices, including digital communication.

The first of these is paying attention to writtenness and the regulation of space. Each mode of communication is highly regulated, offering specific definite material constraints, recognisable routines and conventions and possibilities for creativity. These are socially shaped and indeed in turn can be recognised as shaping society. In material terms, the Edwardian postcards are each a specific size and include restrictions as to how much of the 
space can be used for what purpose. As has been seen, commercial publishers produced postcards for the public to select from and buy, but also common was the practice of commissioning or creating one's own cards, according the regulations, as card 1 . The turn of the century format of card 7 only permitted a very short message in the margin of an image. But that message could be handwritten. In the first decade of the twenty-first century the length of SMS (text) messages was very constrained; a constraining feature of the popular microblogging platform Twitter was a limit on length of 140 characters. Neither variations of font or text colour, nor the use of freeform handwriting were found among the semiotics of microblogging in a recent one year study (Gillen and Merchant 2012); although of course as any other digital platform Twitter possessed material affordances that the Edwardian postcard did not.

While there are some cards in our dataset that include more than100 words in the message, none of the cards in this sample contains a great deal of writing. The sender of card 10, for example, demonstrates maximum use of the space afforded on the card, without contravening regulations. Both that sender and the addressee would readily have understood the writing practices here, the full address, the stamp, and the communicative marks made by third parties: the directions for use of the space that have been partially covered over as familiar by the publisher (probably commissioned by Manchester Cathedral as no commercial logo is included) and the postmark applied by the Post Office. As demonstrated by this sample, postcard users understood these regulatory systems: which elements could be slightly contravened if necessary, as where pre-printed writing is overwritten by senders, and which cannot be, such as the positioning of the stamp and address. 
Second, the dynamic of public versus private is clearly of much interest to those interested in digital communications as indeed to the broader public; text messages, tweets and so forth currently appear almost daily at the heart of mass media news coverage. Even though postcards can be thought of as an epistolary genre, perhaps prototypically dyadic, their semi-public nature has been recognised (Östman, 2004). Open to the readership of others, (especially the postman, a frequent visitor to one's door, and potentially anyone in the household) they were regarded in their own time as public communications. As with Twitter today, this could render users liable to legal action and other sanctions. The Times newspaper reported in 1905 that Melita Macready, a music teacher, had been charged with defamatory libel, having 'published on a postcard which she sent to the principal of the Guildhall School of Music, 'You old rogue, villain and liar. You old coward. Why don't you fight.' She was committed for trial.

Third and finally, it can be fascinating to investigate the reasons that make a particular communications technology extremely popular and perceived as generally accessible whatever the actual constraints. Approaches that move beyond text analysis, that seek to probe social attitudes permeating and surrounding use of a communications technology illuminate the norms that users orient to and often work with in creative ways. Communications technologies evolve and fade. With rising costs of raw materials, the struggle for better working conditions for postmen, and many changes attributable to the Great War, the postcard did not vanish but became more expensive, less speedy and faded into relatively occasional use (Clinton 1984; Daunton 1985; Staff 1979). It never again attained anything like its popularity in the Edwardian Age, claimed to be rivalling the Internet of today (Palcewski 2005). Significant was not just its seeming ubiquity but the sense at the time that the postcard epitomised something of the culture of an age described in ways that 
resonate with the contemporary digital era, and its consciousness of mobilities of people and language.

The new communications technologies allowed more words to travel faster and farther than was heretofore possible, creating the impression of a world simultaneously shrinking and coming apart. (Keep (2001: 153)

The writing practices of Edwardian postcard users, their appropriation of the innovation and the diversity of ways in which they made use of the opportunities offered, provide us with windows into their performances of social identities and relationships. In considering new frameworks for the sociolinguistics of writing of the present, it can be fruitful to gaze back into the past. I have brought a historical methodology to Literacy Studies through the construction of text histories and in so doing illuminated a fascinating communications technology and semiotic artefact. 


\section{NOTES}

1. I acknowledge with thanks the contribution of Nigel Hall, with whom I am researching Edwardian postcards. Thanks are also due to Jane Demmen, June Hall, Jeanette Riglin and Joanne Thistlethwaite for their assistance to the project. The Buxton Museum and Art Gallery provided some information regarding Miss Janet Carmichael. I am grateful to the editors of this special issue and the journal's editor as well as three anonymous reviewers for exceptionally constructive and helpful reviews.

2. The Edwardian period is variously understood as 1901-1910, the death of Edward VII, or alternatively as ending with the advent of the Great War in 1914.

3. All ages are accurate to within 2 years. It is possible, at a cost, to investigate the precise date of birth but we have not usually done this. 


\section{REFERENCES}

Altick, Richard. 1957. The English Common Reader: a Social History of the Mass Reading Public 1800-1900. Chicago: University of Chicago Press.

A member of the aristocracy. 1892. The Correct Guide to Letter Writing $5^{\text {th }}$ edn. London and New York: Frederick Warne and Company.

Androutsopoulos, Jannis (2008) Discourse-centred online ethnography. In: Androutsopoulos, Jannis and Michael Beißwenger (eds.) (2008) Data and Methods in Computer-Mediated Discourse Analysis. Special Issue, Language@Internet 5 http://www.languageatinternet.de Baron, Naomi. 1998. Letters by phone or speech by other means: the linguistics of email. Language \& Communication 18: 133-170.

Barton, David. 2007. Literacy: an Introduction to the Ecology of Written Language, $2^{\text {nd }}$ edn. Oxford: Blackwell.

Barton, David and Nigel Hall (eds.). 1999. Letter Writing as a Social Practice. Amsterdam: John Benjamins.

Barton, David and Mary Hamilton. 1998. Local Literacies: Reading and Writing in One Community. London: Routledge.

Barton, David and Carmen Lee. 2013. Language Online: Investigating Digital Texts and Practices. London: Routledge.

Barton, David and Uta Papen (eds.). 2010. The Anthropology of Writing: Understanding Textually Mediated Worlds. London: Continuum.

Bauman, Richard. 2010. 'It's not a telescope, it's a telephone': Encounters with the telephone in early commercial sound recordings. In Sally Johnson and Tommaso Milani (eds.). Language Ideologies and Media Discourse: Texts, Practices, Politics. London: Continuum. 252-276 . 
Baym, Nancy. 2010. Personal Connections in the Digital Age. Cambridge: Polity. Bazerman, Charles and Paul Prior. 2004. Introduction. In Charles Bazerman and Paul Prior (eds. ) What Writing Does and How It Does It: An Introduction to Analyzing Texts and Texual Practices. Mahwah, NJ: Lawrence Erlbaum. 1-10.

Becker, Barbara and Karen Malcolm. 2008a. Suspended conversations that intersect in the Edwardian postcard. In Nina Nørgaard (ed.). Systemic Functional Linguistics in Use. Odense working papers in language and communication vol. 29.

Becker, Barbara and Karen Malcolm. 2008b. Visual and verbal repositories of Edwardian cultural values and attitudes. Unpaged manuscript.

Biber, Douglas. 1998. Variation Across Speech and Writing. Cambridge: Cambridge University Press.

Bickerton, Derek. 2003. Symbol and structure: a comprehensive framework for language evolution. In Morten H. Christiansen and Simon Kirby (eds.) Language Evolution. Oxford: Oxford University Press. 77-93.

Blom, Philipp. 2008. The Vertigo Years: Change and Culture in the West, 1900-1914. London: Weidenfield and Nicholson.

Blommaert, Jan. 2005. Discourse: A Critical Introduction. Cambridge: Cambridge University Press.

Brooksbank, Frank Henry. 1908. Essay and Letter Writing, with Models and Outlines. London: Macmillan and Company.

Cabrita, Joel. 2010. Texts, Authority, and Community in the South African 'Ibandla lamaNazaretha' Church of the Nazaretha, 1910-1976. Journal of Religion in Africa, 40: 6095.

Carline, Richard. 1971. Pictures in the Post: The Story of the Picture Postcard and its Place in the History of Popular Art. London: Gordon Fraser Gallery. 
Clinton, Alan. 1984. Post Office Workers: A Trade Union and Social History. London: George Allen and Unwin.

Crow, D. 1972. The Edwardian Woman. London: George Allen and Unwin.

Crystal, David. 2006. Language and the Internet, 2nd. edn. Cambridge: Cambridge University Press.

Danet, Brenda. 1997. Books, letters, documents. Journal of Material Culture 2: 5-38.

Daunton, M.J. (1985) Royal Mail: The Post office Since 1840. London: Athlone Press.

Douglas, James. 1909. Adventures in London. London: Cassell and Co. Ltd.

Donnachie, Ian and Innes Macleod. 1979. Victorian and Edwardian Scottish Lowlands from historic photographs. London: B.T. Batsford.

Durston, Alan. 2008. Native-language literacy in colonial Peru: the question of mundane Quechua writing revisited. Hispanic American Historical Review 88: 41-70.

Florio-Ruane, Susan and Mary McVee. 2002. Ethnographic approaches to literacy research. In Michael Kamil, Peter Mosenthal and P. David Pearson (eds.) Methods of Literacy Research: The Methodology Chapters from the Handbook of Reading Research Vol. III. Mahwah, NJ: Lawrence Erlbaum Associates. 77-86

Gee, James P. and Elisabeth Hayes, E. 2011 Language and Learning in the Digital Age. London: Routledge.

Gillen, Julia. forthcoming. Digital Literacies. London: Routledge.

Gillen, Julia and Nigel Hall. 2010a. Any mermaids? Tracing early postcard mobilities. In J. Urry, M.Büscher \& K. Witchger (eds) Mobile Methods. London: Routledge. 20-35.

Gillen, Julia and Nigel Hall. 2010b. Edwardian postcards: illuminating ordinary writing. In David Barton and Uta Papen (eds) The Anthropology of Writing. London: Continuum. 169189. 
Gillen, Julia and Guy Merchant. 2012. Contact calls: Twitter as a dialogic social and linguistic practice. Language Sciences 35: 47-58.

Hall, Nigel. 1999. The materiality of letter writing: a nineteenth century perspective. In David Barton and Nigel Hall (eds.) Letter Writing as a Social Practice. Amsterdam: John Benjamins. 83-108.

Hannavy, John. 2011. The Victorians and Edwardians on the Move. Oxford: Shire Publications.

Heath, Shirley Brice. 1983. Ways with Words. London: Cambridge University Press. Hensher, Philip. 2012. The Missing Ink: The Lost Art of Handwriting, and Why it Still Matters. London: Pan Macmillan.

Heaton, J. Henniker (1896) To the editor of The Times. The Times March 14. 5.

Herring, Susan. 2004. Slouching toward the ordinary: Current trends in computer-mediated communication. New Media \& Society 6: 26-36.

Hook, Sara. 2005. You've got mail: hospital postcards as a reflection of health care in the early twentieth century. Journal of the Medical Library Association 93: 386-393.

How, James. 2003. Epistolary Spaces: English Letter Writing from the Foundation of the Post Office to Richardson's Clarissa. Aldershot: Ashgate Publishing.

Hunter, John. 1872. A School Manual of Letter Writing. London: Longmans, Green and Company.

Hymes, Dell. 1982. What is ethnography? In Perry Gilmore and Allan Glatthorn. (eds.) .Children In and Out of School: Ethnography and Education. Washington, DC: Center for Applied Linguistics. 21-32.

Jaffe, Alexandra. 1999. Packaged sentiments: the social meaning of greeting cards. Journal of Material Culture 4: 115-141. 
Jaworski, Adam. 2010. Linguistic landscapes on postcards: tourist mediation and the sociolinguistic communities of contact. Sociolinguistic Studies 4: 569-594.

Johnson, Amy Suzanne and Lauren Cowles. 2009. Orlonia's 'literacy-in-persons': Expanding notions of literacy through biography and history. Journal of Adolescent and Adult Literacy, 52: 410-420.

Keep, Christopher. 2001. Blinded by the type: Gender and information technology at the turn of the century. Nineteenth-Century Contexts 23: 149-173.

Kress, Gunther. 1998. Visual and verbal modes of representation in electronically mediated communication: the potentials of new forms of texts. In Ilana Snyder (ed.). Page to Screen: Taking Literacy into the Electronic Era. London: Routledge. 3-79.

Laakso, V. and Jan-Ola Östman. (eds.) (1999). Postikortti diskurssina [The postcard as discourse]. Hämeenlinna: Korttien Talo.

Lauder, Leonard A. (2012) Messages from the postcard age. In Lynda Klich and Benjamin Weiss The Postcard Age: Selections from the Leonard A. Lauder Collection. London: Thames and Hudson. 24-29.

Lombard, Matthew and Theresa Ditton. 1997. At the heart of it all: the concept of presence. Journal of Computer-Mediated Communication 3.2 http://jcmc.indiana.edu/vol3/issue2/lombard.html accessed 20 March 2013. (unpaged) McQuire, S. (2008. The Media City: Media, Architecture and the Urban Space. London: Sage.

Malcolm, Karen and Barbara Becker. (2008). Edwardian postcards as an insight into the Edwardian mind and community. In M. Harry et al. (eds.) Proceedings of the Atlantic Provinces Linguistic Association 2007. Atlantic Provinces Linguistic Association. 59-65. Manchester Weekly Times. 1890 . Talking by the card. June $4^{\text {th }} .4$. 
Milne, Esther. 2010. Letters, Postcards, Email: Technologies of Presence. New York: Routledge.

Östman, Jan-Ola. 2004. The postcard as media. Text 24: 423-442.

Page, Ruth. 2012. Stories and Social Media. London: Taylor and Francis.

Palczewski, Catherine. 2005. The male Madonna and the feminine Uncle Sam: visual argument, icons, and ideographs in 1909 anti-woman suffrage postcards. Quarterly Journal of Speech 91: 365-394.

Phillips, Tom. 2000. The Postcard Century. London: Thames and Hudson.

Phillips, Tom. 1999. Letters: embracing letter writing within discourse analysis. In Ian Parker and the Bolton Discourse Network (eds). Critical Textwork: An Introduction to Varieties of Discourse and Analysis. Buckingham, UK: Open University Press.

Prochaska, David and Jordana Mendelson. 2010. (eds.). Postcards: Ephemeral Histories of Modernity. University Park, Pennsylvania: The Pennsylvania State University Press.

Rogan, Bjarne. 2005. An entangled object: the picture postcard as souvenir and collectible, exchange and ritual communication. Cultural Analysis 4: 1-27.

Scribner, Sylvia and Michael Cole. 1981. The Psychology of Literacy. Harvard University Press.

Seargeant, Philip, Caroline Tagg and Wipapan Ngampramuan. 2012. Language choice and addressivity strategies in Thai-English social network interaction. Journal of Sociolinguistics 16: $510-531$.

Sebba, Mark. 2007. Spelling and Society: The Culture and Politics of Orthography Around the World. Cambridge, Cambridge University Press.

Siegert, Bernhard. 1999. Relays: Literature as an Epoch of the Postal System. (Trans. Kevin Repp.) Stanford, California: Stanford University Press.

Sims, George. 1900. The Picture Post Card. August 22. 
Sokoll, Thomas. 2001. Essex Pauper Letters 1731-1837. Oxford: Oxford University Press. Street, Brian. 1984. Literacy in Theory and Practice. Cambridge: Cambridge University Press.

Staff, Frank. 1979. The Picture Postcard and its Origins $2^{\text {nd }}$ edn. London: Lutterworth Press. Stevens, Norman D. (1995) (ed.), Postcards in the Library: Invaluable Visual Resources. Binghamton, New York: Haworth Press.

Tagliamonte, Sali A. and Derek Dennis. 2008. Linguistic ruin? Lol! Instant messaging and teen language. American Speech 8: 3-34.

Thompson, Paul. 1992. The Edwardians: The Remaking of British Society. $2^{\text {nd }}$ edn. London: Routledge.

Thurlow, Crispin and Kristine Mroczek (eds.). 2011. Digital Discourse: Language in the New Media. Oxford: Oxford University Press.

The Times. 1889. The history of the post-card, from a correspondent. November 1. 4. The Times. 1905. Charge of libel. May 20. 16.

Tolstoy, Leo. (1898[1855]) Recollections of a billiard-marker. In The Complete Works of Lyof N. Tolstoi, vol. 7 (Trans. Nathan Haskell Dole.) New York: Thomas Crowell and Company. http://en.wikisource.org/wiki/Recollections_of_a_Billiard-marker accessed 27 March 2013.

Urry, John. 2007. Mobilities. Cambridge: Polity.

Wall, Richard. 2007. Family relationships in comic postcards 1900-1930. History of the Family 12: 50-61.

Wollaeger, Mark 2001. Woolf, postcards, and the elision of race: colonizing women in The Voyage Out. Modernism/modernity 8: 43-75 
